\title{
Y VE Z KUŞAKLARININ İŞ HAYATINDAN BEKLENTILERININ KARŞILAŞTIRILMASI
}

Ayşegül DÜZGÜN ${ }^{1}$

Atıf/(): Düzgün, A. (2020). Y ve Z kuşaklarının iş hayatından beklentilerinin karşılaştırılması. Hitit Üniversitesi Sosyal Bilimler Enstitüsü Dergisi, 13(1), 218-241. doi: 10.17218.hititsosbil.734483

Özet: $\mathrm{Bu}$ araştırmanın ana amacı, Y ve Z kuşaklarının iş hayatından beklentilerinin ortaya konulması, bu kuşakların iş hayatından beklentilerinin karşılaştırılması ve bu beklentilerin kuşak yöneticilerine ışık tutması amacı ile aktarılmasıdır. Araştırmanın ilk bölümünde kuşaklar hakkında bilgi verilmiştir. İkinci bölümünde ise $Y$ kuşağı ile 21. yüzyıl iş hayatı için önem teşkil eden $Z$ kuşağının iş hayatından beklentileri üzerine bir araştırma yapılmıştır. Araştırmada kullanılan anket formu Gümüşhane Üniversitesi öğrencilerine uygulanmış ve anket sonucu elde edilen veriilerden faydalanılmıştır. Araştırma kapsamında bağımsız gruplar t testi analizi uygulanmıştır. Araştırmada $Y$ ve $Z$ kuşaklarının iş hayatından iletişim ve karar verme konularında aynı beklentilere; örgüt kültürü, lider, takım çalışması, motivasyon ve gelişme konularında ise farklı beklentilere sahip olduğu sonucuna ulaşılmıştır.

Anahtar Kelimeler: Y kuşağı, Z kuşağı, İş hayatından beklenti

\section{Comparison of the Expectations of the Business Life of $Z$ and $Y$ Generation}

Citation/@: Düzgün, A. (2020). Comparison of the expectations of the business life of $z$ and y generation. Hitit University Journal of Social Sciences Institute, 13(1), 217-241. doi: 10.17218.hititsosbil.734483

Abstract: The main purpose of this research is to reveal the expectations of the generations named $\mathrm{Y}$ and $\mathrm{Z}$ from business life, to compare the expectations of these generations and transmit to its executive with the aim of shedding light. In the first part of the research, information about generations is given. In the second part, a research was conducted on the expectations of generation $\mathrm{Y}$ with $\mathrm{Z}$ generation, which are important for 21 st century business life, from business life. The questionnaire form used in the research was applied to the students of Gümüşhane University and the data obtained from the questionnaire was used. Independent groups $t$ test analysis was used in the research. As a result of the research, it has been concluded that the $Y$ and $Z$ generations have same expectations from the business life in terms of communication and decision making. As a result of the research, it has been concluded that theY and $Z$ generations have different expectations from the business life in terms of organizational culture, leader, team work, motivation and development.

Keywords: Y Generation, $Z$ Generation, Expectations of the Business Life

\section{GİRIŞ}

Dünyada yaşanan savaşların, buhranların, toplumsal olayların (kadın özgürlüğü vb.), küreselleşme, liberalleşme ve özelleştirmenin, siyasi, sosyal ve teknolojik değişimlerin insanlar üzerinde de etkisi olmuş ve yaşanan değişim ve gelişmeler bu dönemlerde yaşayan kişilerin özelliklerini de etkilemiştir. Dolayısıyla farklı dönemlerde yaşayan insanların özellikleri de yaşadıkları dönemin koşullarına göre değişiklik göstermektedir. Bu durumun bir sonucu olarak

Makale Geliș Tarihi: 8.5.2020 Makale Kabul Tarihi: 29.6.2020

Etik Kurul Onayı: Gümüşhane Üniversitesi Bilimsel Araştırma ve Yayın Etiği Kurulu'nun 2020/4 sayı ve 07.04.2020 tarihli toplantısında görüşülmüş ve kabul edilmiştir.

1 Dr. Öğr. Üyesi, Gümüşhane Üniversitesi, İktisadi ve İdari Bilimler Fakültesi, duzgunaysegul29@gmail.com, https://orcid.org/0000-0002-5716-671X 
da kuşaklar ve kuşaklar arasındaki farklılıklar ortaya çıkmıştır. Söz konusu değişim ve gelişmelerin bir yansıması olan kuşak farklılıkları iş hayatını da etkilemektedir. Dolayısıyla amaçlarına ulaşmak isteyen işletmelerin çalıştırdıkları insanların da iş hayatından beklentilerinin değiştiğinin farkında olup çalışanlarını elde tutabilmek için bu kişilerin özelliklerini bilmek, onlara yönelik çalışma koşullarını değiştirmek ve iyileştirmek gibi bir takım faaliyetlerde bulunması gerekmektedir. İlgili literatürde Taşlıyan ve diğerleri (2015) tarafından yapılan Y kuşağının iş yaşamından beklentilerinin neler olduğunu belirlemeye yönelik bir çalışmaya rastlanmış olmakla birlikte $Z$ kuşağına dair böyle bir çalışmanın özellikle de her iki kuşağın iş yaşamından beklentilerinin neler olduğunun karşılaştırıldığı bir çalışmanın varlığına tarafımızca rastlanılamamıştır. Günümüz iş hayatında Y kuşağı hala aktif olmakla birlikte gelecek yıllar içerisinde iş hayatında daha fazla yer alacak olan ve teknolojinin içinde doğup büyüyen $Z$ kuşağının farklı düşünce yapısının iş hayatına önemli katkılar sağlayacağı düşünülmektedir. $\mathrm{X}$ ve $\mathrm{Y}$ kuşaklarından sonra iş hayatında yavaş yavaş yer almaya başlayan $Z$ kuşağının iş hayatından beklentilerinin neler olduğunun belirlenmesi ve bu beklentilerin bir önceki kuşak olan Y kuşağ1 ile karşılaştırılması ve bu karşılaştırma sonucunun yeni kuşak yöneticilerine aktarılması işletmelerin amaçlarına ulaşabilmesi açısından önem arz etmektedir. Çalışmanın önemi ilgili literatürdeki boşluğu dolduracak olması ve işletme üst düzey yöneticilerine kuşaklar arasındaki benzerlik ve farklılıkları anlatmak yoluyla onları bilgilendirecek olmasından kaynaklanmaktadır. Bu bağlamda, bu çalışma $Y$ ve $Z$ kuşaklarının iş hayatından beklentilerinin neler olduğunu belirlemek ve söz konusu beklentileri karşılaştırılmayı, elde edilen sonuçları ise kuşak yöneticilerine 1şık tutması amacı ile aktarmayı amaç edinmiştir.

Y ve $Z$ kuşaklarının iş hayatından beklentilerini belirlemeye çalışan araştırmada öncelikle kuşak kavramı ile ilgili literatüre değinilmiş ardından çalışmanın amaç ve öneminden bahsedilmiştir. Çalışmanın son bölümünde ise yönteme, analize, bulgulara ve sonuca yer verilerek çalışma sonlandırılmıştır.

\section{2. ÇALIŞMANIN KAVRAMSAL ÇERÇEVESI VE ARAŞTIRMA SORULARI}

Kuşaklar konusu ile ilgili ekonomi, siyaset bilimi, demografi, sosyoloji, klinik psikoloji vb. alanlarda 50 yıldan fazla zamandır çalışmalar yapılmaktadır (Alwin ve McCammon, 2007; Biggs, 2007). Bireyleri birbirlerine bağlayan paylaşılan doğum yıllarında meydana gelen belirli tarihsel olaylar, bireyler için ortak deneyimler haline gelir ve onların kritik gelişim yıllarını büyük ölçüde etkiler. Bununla birlikte, doğum yıllarını paylaşan bireyler, birbirleriyle grup içi üye olarak tanımlanırken, grup dışındaki diğerleri de onları ayrı bir kuşak olarak tanır. Böylece ilgili kuşaklardaki bireyler yalnızca paylaşılan doğum yılları ile değil aynı zamanda üyelerin özelliklerini kalıcı olarak etkileyen benzersiz sosyal ve tarihi deneyimleriyle de diğer kuşaklardan ayırt edilebilir (Sullivan ve diğerleri, 2009, s. 288). Her kuşağın kendine has özellikleri, temel değer ve tutumları, güçlü ve zayıf yönleri vardır (Lower, 2008, s. 80). Benzer şekilde Twenge ve diğerleri (2010, s. 1120) de kritik gelişim dönemlerinde kendine özgü tarihi ve sosyal yaşam olaylarını paylaşan aynı zamanlarda doğmuş bireyleri kuşaklar olarak tanımlamaktadır. Yazarlara göre her kuşak, onları farklı zamanlarda büyüyen insanlardan ayıran ortak değer sistemlerini oluşturan geniş güçlerden (yani ebeveynler, akranlar, medya, kritik ekonomik ve sosyal olaylar ve popüler kültür) etkilenmektedir.

\subsection{Kuşak Türleri}

20. yüzyılda, yoğun savaşlardan dolayı kuşaklar sosyal ve tarihi olaylara uygun olarak adlandırılmıştır (Levickaite, 2010, s. 171). Kuşakların sınıflandırılması ile ilgili literatürde farklı tarihler yer almakla birlikte bu çalışmada en çok yapılan sınıflandırma dikkate alınmıştır. 
Tablo 1. Kuşak sınıflandırmaları

\begin{tabular}{ll}
\hline Kuşaklar & Yaşadı̆̆ dönemler \\
\hline Gelenekselciler & $1922-1945$ \\
\hline Bebek Patlaması & $1946-1964$ \\
\hline X Kuşağ1 & $1965-1980$ \\
\hline Y Kuşağ1 & $1981-2000$ \\
\hline Z Kuşağı & $2001-2020$ \\
\hline
\end{tabular}

Kaynak: Bayhan, V., 2017, s. 322'den esinlenerek oluşturulmuştur.

\subsubsection{Gelenekselciler}

Büyük buhran dönemine denk gelen ve 2. Dünya savaşında savaşan gazileri içeren gelenekselciler kuşağı (Levickaite, 2010, s. 171) en eski kuşağ1 oluşturmakla birlikte bu kuşaktaki kişilerin çoğu şimdilerde emeklidir (Tolbize, 2008, s. 2). Gaziler, sessizler, sessiz kuşak, olgunlar, en büyük kuşak olarak da bilinen bu kuşak, 1945’ten önce doğmuş bireyleri içermesine rağmen bazı kaynaklarda ilk doğum yılı 1922 olarak da yer almaktadır (Tolbize, 2008, s. 2). Büyük Buhran ve II. Dünya Savaş1, "En Büyük Nesil” in zihniyetini şekillendiren kritik olaylardır (Kerstein, 2014, s. 4). Bu kuşağın işçileri sadık çalışanlar, yüksek düzeyde kendilerini adamış, riskten kaçınan ve ekip çalışmasına ve işbirliğine güçlü bir şekilde bağlı olan kişiler olarak nitelendirilmektedir (Tolbize, 2008, s. 2). Bununla birlikte bu kuşaktaki işçiler formaliteye ve emir-komuta zincirine önem veren, otoriteye sayg1 duyan kişilerdir (Tolbize, 2008, s. 2; Kerstein, 2014, s. 4). Ayrıca onlar için saygı da önem taşımaktadır öyle ki Randstad tarafından 2001 yılında yapılan bir araştırma, saygının gelenekselcilerin en büyük psikolojik ihtiyacı olduğunu göstermektedir (Kerstein, 2014, s. 4).

\subsubsection{Bebek Patlaması Kuşağı}

Unutulmuş kuşak, Woodstock kuşağ1, Sandviç kuşağı ve Vietnam kuşağı olarak da bilinen (Srinivasan, 2012, s. 51) ve II. Dünya Savaşı sırasında doğum oranlarındaki artış ile belirgin bir özelliğe sahip olan (Levickaite, 2010, s. 171) 1946-1964 yılları arasında doğan nesli kapsamaktadır. 19 y1llı süreci kapsayan bu süreçte Amerika'da 75,8 milyon bebek dünyaya gelmiştir ve 1964'teki bu büyük üreme döngüsünün sonunda, nesil ABD nüfusunun yüzde 40'ını temsil etmekteydi (Green, 2006, s. 8). Bu kuşak, önceki nüfus sayımı rakamlarına göre o dönemde doğan fazladan on yedi milyon bebek nedeniyle Bebek Patlaması olarak anılmakta (O'Bannon, 2001, s. 97) ve Amerikan tarihinin en büyük kuşağını oluşturmaktadır. Büyüklükleri ve yaşadıkları zaman nedeniyle bu bireylerin Amerikan ve dünya toplumları üzerinde derin bir etkisi olmuştur. Büyürken karşılaştıkları olaylardan bazıları Rock'n Roll, uzay yarışı ve kadın özgürlüğü idi. Bu olayların etkisi onların azimli, idealist ve iyimser olma yönünde kişiliklerini biçimlendirmiştir (Glass, 2007, s. 99).

Tablo 2. Bebek Patlaması Yılları Boyunca Doğum Oranlarında Artış ve Düşüş

\begin{tabular}{cc}
\hline Y1llar & Doğum Say1s1 \\
\hline 1940 & 2.559 .000 \\
\hline 1946 & 3.311 .000 \\
\hline 1955 & 4.097 .000 \\
\hline 1957 & 4.300 .000 \\
\hline 1964 & 4.027 .000 \\
\hline 1974 & 3.160 .000 \\
\hline
\end{tabular}

Kaynak: O'Bannon, G. (2001). Managing our future: The generation X factor. Public Personnel Management, 30(1), s. 95-110.

Boomer-Xer Gap'ın ortak yazarlarından Connie Fuller, "Bebek patlaması kuşağı yaşamak için çalışan insanlardır" demiştir. Yaklaşık 80 milyon akranla birlikte büyümek bu nesli rekabet gücü yüksek bir kuşak haline getirmiştir. Gelenekselciler gibi bu kuşağın bireyleri de emir- 
komuta zincirine ve saygiya önem vermektedir (Kerstein, 2014, s. 4). Bebek patlaması kuşağ1 fedakârlı̆̆ın başarı için ödenmesi gereken bir bedel olduğuna inanmış (Tolbize, 2008, s. 3; Kerstein, 2014, s. 4) ve bu fedakârlık onlara maddi başarılar kazandırmıştır (Glass, 2007, s. 100). Bebek patlaması kuşağında yer alan kişiler yüz yüze iletişime çok önem vermekte ve muhtemelen ağır ebeveyn yönlendirmesinin ve biçimlendirici yıllarda yaşamanın bir sonucu, detaylara yönelik talimatlar verildiğinde kendilerini daha rahat hissedip işleri doğru yapabilmekteydi. Bu kuşağın bireyleri iş arkadaşlarının ve yöneticilerinin tecrübelerini ve günlük çabalarını takdir etmelerini istemektedir. Bununla birlikte bu kuşağın bireyleri, meydan okuyabilecekleri ve sonuçlara katkı sağlayabilecekleri bir ortam istemektedirler (Glass, 2007).

Amerika'daki Vietnam Savaşı politikaları, birçok kişinin daha büyük bir amaç için iç huzurunu feda etmesine neden olmuştur. Bebek patlaması kuşağında yer alan bireyler ise bu mücadelede eşitlikçi ve barış seven bir toplum oluşturma ortak hedefini paylaşmışlardır (Green, 2006, s. 18). Bununla birlikte kuşak, sosyal kurumlara ve otoriteye sayg1 duymayan kendini tatmin etmeyi tercih eden bencil olarak nitelendirilmektedir. Ayrıca bu kuşağın çalışanları için temel motivasyon kaynağı para, bir ofise sahip olma ve kendini gerçekleştirme ihtiyacıdır (Srinivasan, 2012, s. 51).

20. yüzyılın ikinci yarısı, hem siyasi çevre hem de teknolojik yenilikler açısından zorlayıcıydı. Kuşak terimi, biyolojik veya tıbbi olmaktan çok, sosyal açıdan daha da ileri gitmiştir. Gelecek üç kuşak $(\mathrm{X}, \mathrm{Y}, \mathrm{Z})$ politik, sosyal ve teknolojik değişimlere doğal bir cevaptır (Levickaite, 2010, s. 172).

\subsubsection{Kuşağı}

Bebek patlaması kuşağından sonra doğan X kuşağı Batı kültüründe demografik, sosyal, kültürel bir sosyal grubu tanımlamakta ve 1960 ve 1970'li yıllarda doğan insanları kapsamaktadır. Terim 1964 yılında gençlerle bir dizi röportaj gerçekleştiren Amerikalı ve İngiliz araştırmacılar Charles Hamblett ve Jane Deverson tarafından verilmiştir (Levickaite, 2010, s. 172). Bu kuşak şüpheci, eğlenceli ve doğası gereği gayrı resmidir (Golovinski, 2011, s. 31). Bu kuşak özellikle daha küçük bir aile olma kararı ve doğum kontrolüne daha kolay erişebilme gibi nedenlerle sayıca bebek patlaması kuşağından önemli ölçüde azdır (Glass, 2007, s. 99). Çalışan annelerin sayısının artması ile birlikte daha yüksek boşanma oranları birçok X kuşağı bireyinin evde yalnız ve cihazlarla büyümelerine sebep olmuştur (Kerstein, 2014, s. 4). X kuşağ1, ev bilgisayarının başlangıcını, video oyunlarının yükselişini ve interneti sosyal ve ticari amaçlar için bir araç olarak görerek olgunlaşmıştır (Levickaite, 2010, s. 173).

$\mathrm{Bu}$ kuşağın çalışanları iş yaşam dengesine önem veren, şüpheci ve bireysel çalışanlar olma eğilimindedir. Çoğu, meslekte ilerlemek yerine fazladan izinle ödüllendirilmeyi tercih etmekte, fazladan çalışma saatleri gerekli olduğunda geri durmayı tercih etmekteydi (Kerstein, 2014, s. 4). $X$ kuşağ bireyleri, kendini geliştirme konusunda önemli bilgileri öğrenmek ve kullanmak için fırsatlar aramaktaydı (Glass, 2007, s. 102). X kuşağı bireyleri için iletişim direkt ve derhal olmalıdır (Golovinski, 2011, s. 32).

X kuşağı için en önemli değerler, girişimcilik ve özerklik, yeni bir şeyler öğrenme becerisine sahip olma duygusudur. Statüko ve hiyerarşik ilişkiler konusunda şüpheci olma eğilimindedirler (Jurkiewicz, 2000, s. 57). X kuşağ yöneticileri, çalışanların yeteneklerini geliştirebilecekleri ve kariyerlerini biçimlendirebilecekleri ilgi çekici bir vizyon ve değerler kümesi sunarlar. Bununla birlikte çalışanların kişisel sorumluluk üstlenmelerini ve bireysel inisiyatifi vurgularlar (Buckley ve diğerleri, 2001, s. 81). 


\subsubsection{Y kuşağ1}

1981-2000 yılları arasında doğmuş (Golovinski, 2011, s. 33) "İnternet kuşağı", "Echo Boomers", "Millenials", "Nexters", "Generation www", "Dijital Generation”, "E Generation", "N-Gens" olarak da isimlendirilen (Martin, 2005, s. 40; Broadbridge ve diğerleri, 2007, s. 8) Y kuşağ1 bireyleri kendilerini "Nükleer olmayan aile kuşağ1 (Non-Nuclear Family Generation), "Kutsal olmayan kuşak (the Nothing-Is-Sacred Generation)", "Taklitçi (the Wannabees)", "İyi hisseden kuşak (the Feel-Good Generation), "Siber çocuklar (CyberKids)", "Yap ya da öl kuşağı (the Do-or-Die Generation)" ve "Kimlik arayan kuşak" olarak daha yaratıcı bir şekilde ifade etmektedirler (Martin, 2005, s. 40). Krek kokain, modifiye ilaçlar ve AIDS salgını gibi ürkütücü olaylar arasında büyümüş olan Y kuşağı üyelerinin birçoğu tam zamanlı işe girmeden önce daha öğrenci iken birkaç işte çalışarak iş tecrübesine sahip olmuştur (Tulgan ve Martin, 2001, s. 1).

Y kuşağının kariyer tercih ve davranışları, başkalarına yardımcı olan anlamlı işlerde anlamlı roller oynama şansı arayışları ile yönlendirilir. Bununla birlikte, Y kuşağı bireyleri, motivasyonu yüksek birbirine bağlı bir ekibin parçası olmak istemektedir. Ayrıca, Y kuşağı bireylerinin yüksek finansal ve kişisel hedefleri bulunmaktadır (Tulgan ve Martin, 2001, s. 13-15).

Tulgan ve Martin (2001, s. 4), Y kuşağı ile ilgili gerçekleri aşağıdaki gibi sıralamışlardır;

-Özgüven dolu, neşeli bir güven nesli,

-Tarihteki en eğitimli kuşak,

-Daha açık, hoşgörülü bir toplumun yolunu açan bir nesil,

-Gönüllülük dalgasına öncülük eden bir nesil.

Broadbridge, Maxwell ve Ogden (2007) ise Y kuşağının özelliklerini aşağıdaki tablo ile sunmuştur.

Tablo 3. Y Kuşağının Özelikleri

\begin{tabular}{llll}
\hline & Bağımsız & Mevcut durumu bozması muhtemel & Umutlu \\
\cline { 2 - 4 } & İyi eğitimli & Girişimci düşünür & Yetenekli \\
\cline { 2 - 4 } & Kendinden emin & Özgüvenli & Vatanperver \\
\cline { 2 - 4 } & İyimser & Etnik olarak çeşitli & İsirlikçi \\
\cline { 2 - 4 } & Hirslı & Pozitif & Kucaklayıcı \\
\cline { 2 - 4 } & Açık görüşlü & Ebeveynlerine saygılı & Medeni fikirli \\
\cline { 2 - 4 } & Girişken & Finansal olarak güçlü & Nazik \\
\cline { 2 - 4 } & Teknik olarak okuryazar & Az çok yatırım yapan & Meraklı \\
\cline { 2 - 4 } & Yavaşliktan hoşlanmaz & Güçlü sosyal stresörlerle yaşamış & Enerjik \\
\cline { 2 - 4 } & Son derece bilgili & Ünlü olmak isteyen & \\
\hline
\end{tabular}

Kaynak: Broadbridge, A. M., Maxwell, G. A., ve Ogden, S. M. (2007). 13_2_30: Experiences, perceptions and expectations of retail employment for generation Y. Career Development International, s. 1-39.

Tabloda 3’te görüldüğü üzere Y kuşağı bağımsızlığı tercih eden, iyi eğitimli, kendine güvenen, iyimser, hırslı, açık görüşlü, girişken vb. özelliklere sahiptir.

Martin (2005) Y kuşağı bireylerinin sahip oldukları ortak özelliklerini ve yöneticilerin bu özelliklerden nasıl faydalanıp yüksek performansı yakalayacağına dair birtakım öngörü ve stratejiler sunmuştur. Bunlar; 
Tablo 4. Y Kuşağının Ortak Özellikleri ve Yöneticiler için Öngörü ve Stratejiler

Y Kuşağının Ortak Özellikleri

Özgüvenli ve bağımsızdır; Ebeveynlerinin yüksek

boșanma oranları ve/veya çift gelirli ailelerin artmasıyla, kendi cihazlarına bırakılmış ve kendilerine bakmayı öğrenmişlerdir. Bunun sonucu olarak birçoğu özgüven sahibidir ve "elbette kendim için savașabilirim" düşüncesindedir. Y kuşağı açık açık talimatlar ve yönetim desteği ister fakat aynı zamanda görevi kendi yöntemlerine göre, kendi hızlarında gerçekleştirme özgürlügünü ve esnekliğini talep ederler.

Teknoloji meraklısıdır; Teknoloji, bu dijital neslin öğrenme şeklini ve bilgiyi işleme şeklini biçimlendirmiştir.

Aciliyet duygusuna sahiptir; Bir y1l bir Y kușağı için uzu vade ve üç yıl sadece bir seraptır. Onlar merdivenleri tırmanma, aidat ödemeleri ve emekli olduklarında alacakları para vaatleri ile kandırılmak istemiyorlar. Onlar bugün hangi değeri elde edebilecekleri, bugün ne öğrenebilecekleri, bugün kendilerine ne sunulacağı ve bugün nasıl ödüllendirileceklerini bilmek isterler.

Girişimcidir; Tarihin en girişimci nesli X kuşağıydı. Taa ki Y kuşağına kadar.

Artan sorumluluk isterler; Baby Boomer yöneticileri yıllardır çalışanlarından hiç kimsenin daha fazla sorumluluk almak istemediğinden sikayetçiydi. Yöneticiler için hos bir sürprizdir ki Y kuşağı artan sorumluluğu kaçınılması gereken bir yük değil, beceri ve yetenekleri için kanıtlayıcı bir zemin olarak görürler.

\section{Beni rahat birak (get off my back) tavrındadirlar;}

Her kușak gibi Y kuşağı da mikro yönetimden nefret eder. Y kuşağının boş zamanı olsa dahi kolaylıkla sıkılır. Onlara kendileri için zamanı yönetmeleri öğretilmedi.

\footnotetext{
Esneklik isterler; Y kuşağı yeni insanlara, yerlere ve koşullara adapte olmaya hazırdır. Sadece değişimi beklemekle kalmaz onu talep de ederler. Projeden projeye, pozisyondan pozisyona, departmandan departmana, lokasyondan lokasyona geçebilecekleri iş yerleri ararlar. Pazarlanabilir becerileri ögrenmeye devam edebilecekleri ve gelecekte onlara hizmet ederek deneyim toplayabilecekleri firsatlar1 ararlar.

Davranış özgürlüğü tutumunu benimserler; Hem $X$ hem de Y kuşağı büyükbabalarının emekli oldukları yaşam boyu istihdam paradigmasının ölümüne tanık olmuștur. İster kendi isterse baskaları için çalıssıı, Y kuşağı Tom Peters'in "Me, Inc." dediği şeyin sahibi oldu. En iyi genç yetenek, daha yaşlı nesillerin asla düşünemeyeceği şekilde en iyi anlașmaları yapmayı öğrenmektir.
}

\section{Yöneticiler İçin Öngörü ve Stratejiler}

Y kuşağ1 bir takımın üyesi olsun ya da olmasın bir iși yapmanın en iyi yolu olarak zorluklarla mücadele etmeyi sever. Yönetim tarzınızın işbirliğine duyulan ihtiyacı ve ilerleme hızını karşılayacak, deneme ve yanılma zamanını planlayacak kadar esnek olması gerekir.
Y kuşağı teknolojiden yüksek beklentilere sahiplerdir ve teknoloji yeterli olmadığında tahammülsüz olurlar. Kullanmakta olduğunuz teknoloji ne kadar güncel? Sektörünüzdeki diğer işletmelerle rekabet edebiliyor mu? Teknoloji hakkında sizden daha fazla bilgiye sahip olan genç işçilerin yeteneklerinden faydalanmaya hazır mısınız? Ve eğer usta değillerse onları ve tüm çalışanlarını bu konuda nasil hizlandiracaksınız?

Göreviniz bu talepleri karșlayan tam zamanında sistemler geliştirmek. Belirli hedefler, parametreler ve son teslim tarihleriyle ekipleri hızlı bir șekilde çalıștıran uzman bir temsilci olmanız gerekecek. İhtiyacınız olan:

- Eğitim programlarını özelleștirin, böylece genç katılımcılar her yeni görevi yerine getirmek için çabucak hazirlanabilecek,

- Odaklanmıs ve motive olmuş calıșanları tutmak için koçluk becerilerine hâkim olun,

- Performansları için onları sık sık ödüllendiren bir teşvik programı oluşturun,

-Genç yetenekleri ilerlemekten alıkoyan kuruluşunuzdaki eski politikaları ortadan kaldırın.

Meşru bir istek olduğunu düşündüğünüz bir şeye "Neden?" diye sorduklarında şaşırmayın. Genç işçiler size neredeyse her adımda meydan okuyacaklar. Y kuşağı sonsuz seçeneğe maruz kalmıştır. Çeşitli temel inançlar, görüşler ve bakış açılarıyla karşı karşıya kalmıştır. Onlar çoğunlukla diğer seçenekler araştırılıncaya kadar bir çözüme razı olmak istemezler.

Y kuşağının başarısı için artan sorumlulukları ödül olarak nasıl değerlendiriyorsunuz? Etkili bir müzakere şekli odaklanmış ve motive olmuş genç yeteneklerinizi elde tutmaktır.

Y kușağının öğrenmesi gereken ilk becerilerden biri zaman yönetimidir. Günlük kesintilerin ortasında günlük görev ve sorumluluklar ile nasıl baş edeceklerini onlara ögretmeniz gerekir. Onlara daha büyük projeleri yönetilebilir parçalara nasıl ayıracaklarını, zamanlarını nasıl planlayacaklarını ve son teslim tarihlerine nasıl yetiștirebileceklerini öğretmeniz gerekir. Tecrübelerinize dayanarak onlara görevlerin ne kadar sürede bitmesi gerektiği konusunda gerçekçi tahminler vermeniz gerekecek.

Kuruluşunuzda sürekli eğitim, sosyalleşme ve yaratıcılık için firsat ve seçenekler mevcut değilse, genç yetenek onu başka bir yerde bulacaktır. Y kuşağının yaratıcı enerjisinin merkezi haline gelmesi için organizasyonunuzdaki esnekliği nasıl yaratacaksınız? Projeler, eğitim, sosyal aktiviteler, her neyse. Onlara sizinle birlikte kalmaları için bir sebep verin. Ayrılırlarsa daha çok kaybedecekleri, kalmaları için daha fazla sebep.

Devamlı olarak en iyi yeteneklerle en iyi anlaşmaları yaparak bir yetenek avcısı ve uzman bir müzakereci olmanız gerekir.

Gecmişin isyerinde, zorluklarınız eskidendi: Önümüzdeki yirmi yıl boyunca burada iyi insanları nasıl çalıştırabilirim? Yeni işyerinde, bu zorluk kökten değişti. Ve şu şekilde oldu: Bugün ne is yapmam gerekiyor?

İsi bitirmek icin en iyi yetenek kim?

İhtiyacım olduğunda o yeteneğe ulaşabildiğimden nasıl emin olabilirim?

Kaynak: Carolyn, 2005, s. 40'dan esinlenerek oluşturulmuştur.

Y kuşağı önceki kuşakların hayal bile edemediği teknolojiler içinde büyütülmüş bir nesildir. Bu kuşağın yarısı internetli bir dünyaya doğdu. Ayrıca internet, bu kuşak büyürken geliştirilen tek teknoloji değildi. İnternetle birlikte bu kuşağın bireyleri doğduğunda neredeyse cep telefonu 
olmayan kimse yoktu. Bununla birlikte birçoğu üniversiteye başvurmadan önce bir mektup göndermezken ortaokuldan ayrılmadan önce düzenli olarak e-posta gönderiyordu (Golovinski, 2011, s. 33-34). Y kuşağı, neler olup bittiğini bilmek istiyor ve yanlış yönlendirilmek istemiyor (Golovinski, 2011, s. 34).

\subsubsection{Z Kuşağ}

Z kuşağı, "Instant online (anında çevrimiçi)" olarak adlandırılan tam teknoloji kullanıcıların kuşağıdır. Söz konusu kuşak "Generation I (Kuşak I)", "The Internet Generation (İnternet Kuşağ1)", "Generation Next, "Next Generation” (Gelecek Kuşak)", "iGeneration (İ Kuşak)" olarak da isimlendirilmekle birlikte Strauss ve Howe tarafindan "The New Silent Generation (Yeni sessiz kuşak)" olarak isimlendirilmektedir (Levickaite, 2010, s. 173).

Haklarında çok fazla bilgi olmayan $Z$ kuşağı küreselleşme, liberalleşme ve özelleştirme döneminde büyümüştür. Ekonomik gerilemenin zorluklarına tanık olmuş ve çoğunluğu işsizliğin getirdiği zorlukları yaşamış olan $Z$ kuşağı tamamen dijitaldir; onlar her zaman internete bağlıdır, internet dünyasında yaşamaktadır. Dolayısıyla bu kuşağın üyelerinin iletişim ve sosyal etkileşim alışkanlıkları da dijital hale gelmiştir. Diğer bir ifade ile söz konusu kuşağın bireyleri ilişkileri kurmak ve sürdürmek için sosyal ağlara çok güvenmektedir (Tabscott, 2009, s. 6; Levickaite, 2010, s. 173; Mishra, 2012, ss. 96-97).

$Z$ kuşağını önceki kuşaklardan ayıran faktörlerden bir tanesi değişen aile kavramıdır. $\mathrm{X}$ ve $\mathrm{Y}$ kuşağı, kadınların eğitim ve mesleki olarak yükseldiği yeni bir kariyer çağında doğmuşlardı. Oysaki $Z$ kuşağı babaların evde yardımcı olduğu, yeni bir aile çağında doğmuşlardır (Sladek ve Grabinger, 2013, s. 1). Ayrıca, bu kuşağın bireyleri en genç kuşağı oluşturmasına rağmen önceki kuşaklara göre ebeveynleri daha yaşlıdır (İlk çocuk doğduğunda annenin yaşı ortalama 31'dir) ve göreceli olarak daha yaşlı öğretmenlerden eğitim alırlar (öğretmenin yaş1 ortalama 42'dir). Bununla birlikte onlar önceki kuşaklara göre daha erken eğitim almaya başlamış ve daha hızlı büyümektedirler. Ayrıca oldukça genç yaşta pazarlamaya maruz kalmışlardır. İnternet meraklısı, teknolojik okuryazar olan bu kuşak çoklu görevlerle şekillendirilmiş, bir görevden diğerine hızlı bir şekilde hareket etmekte ve hata yapmamaktan ziyade hıza daha çok değer vermektedirler (Mission and Ministry 2010'dan aktaran Levickaite, 2010, s. 173).

Bu kuşağın bireyleri önceki kuşakların bireylerine göre daha bağımsız, daha akıllı ve çeşitliliğe karşı daha toleranslıdır. Onlar bilgileri önceki kuşaklardan daha hızlı yorumlamaktadır. Bu kuşakla ilgili problem ise başa çıkmaları gereken çok fazla bilginin var oluşudur. Yaratıcılı̆̆ keşfetmek için özgürlük istemekte fakat özgürlüğü nasıl yöneteceklerinin farkında değillerdir. İşyerinde iş yerinin ötesinde bir yaşam sürdürmek için esneklik isterler. İstihdam edilebilirlikleri yüksektir. Z kuşağı teknoloji odaklıdır. E-posta gönderebilir, mesaj atabilir ve bilgisayarları rahatlıkla kullanabilirler. Dış dünya ile iletişim kurmak için ağ sitelerini kullanırlar. Hızlı hareket eder ve diğer kuşaklardan daha kısa sürede daha fazla üretebilirler. Önceki kuşaklardan daha farklı davranan, düşünen ve çalışan $Z$ kuşağı bireylerinin teknoloji meraklısı olduğu bilinmekte ancak bundan da ötesi bu kuşağın bireyleri silahlı okul baskını, iklim değişikliği, terörizm ve büyük durgunluk gibi içinde doğdukları krizler tarafindan şekillendirilmiştir. Bu karanlık olaylar şüphesiz bu nesli daha temkinli ve pragmatik hale getirmiş ama aynı zamanda nesle dünyayı değiştirme ilhamı da vermiştir. Dünyayı değiştirmek, sosyal sorumluluk sahibi olmak ve çalışmalarının önemli olduğunu bilmek istiyorlar. Bu kuşağın aynı zamanda yenilikçi ve işbirlikçi oldukları düşünülmektedir. Teknik yeterlilikleri nedeniyle çoklu görevlerde beceriklidirler. Aynı anda mesaj yazabilir, okuyabilir, izleyebilir, konuşabilir ve yemek yiyebilirler. Bu nedenle konsantrasyon düzeyleri çok düşüktür. Karmaş1k 
matematiksel ve istatistiksel verileri analiz etmek ve yorumlamak için ileri teknoloji yazılımları kullanırlar. Uzun süre odaklanamamaları nedeniyle bu tür analizleri manuel olarak yapmaktan çekinirler. $\mathrm{Bu}$ nedenle gelecekte işyerlerinde karar verici pozisyonlarda yetkin kişilerin bulunması noktasında zorluk yaşayabilirler. Stratejik pozisyonlar, analitik düşünebilecek insanları gerektirir oysaki z kuşağ1 bu esnekliğe karşıdır (Tabscott, 2009, s. 6; Mishra, 2012, s. 96-97; Sladek ve Grabinger, 2013, s. 2; Rothman, 2014, s. 5).

Adaleti ve toplumlarının karşılaştığı sorunları şiddetle önemserler ve genellikle okulda, işte veya topluluklarında bir tür sivil faaliyete katılırlar. Bununla birlikte bu kuşağın bireyleri politika ile ilgilidir ve demokrasiyi ve hükümeti dünyayı geliştirmek için kilit araçlar olarak görürler. Hız ve özgürlük için ayarlanmış refleksleri ile güçlenmiş bu gençler, modern yaşamın her kurumunu değiştirmeye başlıyorlar (Tabscott, 2009, s. 6). Z kuşağının mükemmel liderlik becerisine sahip olduğuna ve eşsiz yaşam deneyimleri, becerileri ve değerleri ile işyerinde değişiklik yaratacağına inanılmaktadır (Sladek ve Grabinger, 2013, s. 1).

Sladek ve Grabinger (2013, s. 2)'e göre Y ve Z kuşaklarının her ikisi de teknoloji odaklı olsalar da tamamen birbirinden farklı iki nesildir. Her iki kuşak da hem kişisel hem de işle ilgili sorunlara yaklaşım tarzını etkileyen iki farklı ebeveynlik stili ile büyümüştür. Bu farklılıklar ise Y kuşağının hayalperest, Z kuşağının realist olması, Y kuşağına başarılı olmaları için araçların verilmesi, Z kuşağına başarılı olma becerilerinin öğretilmesi ve Y kuşağının grup odaklı iken $Z$ kuşağının bireyci olması şeklindedir. Bununla birlikte $Z$ kuşağı, Y kuşağına göre daha fazla girişimcidir (Schawbel, 2014, s. 12).

Tablo 5. Z Kuşağının Özellikleri

\begin{tabular}{|c|c|}
\hline Finansal açıdan bilinçli & Sladek ve Grabinger, 2013, s. 4 \\
\hline Küresel fikirli & Sladek ve Grabinger, 2013, s. 4 \\
\hline İș tecrübesi eksik & Sladek ve Grabinger, 2013, s. 5 \\
\hline Teknoloji meraklısı & $\begin{array}{l}\text { Levickaite, 2010, s.173; Mishra, 2012, s. 97; Sladek } \\
\text { ve Grabinger, 2013, s. 5; Schawbel, 2014, s. } 7\end{array}$ \\
\hline Olağanüstü yaratıc1 & $\begin{array}{l}\text { Sladek ve Grabinger, 2013, s. 10; Schawbel, 2014, s. } \\
9\end{array}$ \\
\hline Pratik & Sladek ve Grabinger, 2013, s. 11 \\
\hline Realist & Sladek ve Grabinger, 2013, s. 11 \\
\hline Çoklu görevleri başarabilme & $\begin{array}{l}\text { Levickaite, 2010, s. 173; Mishra, 2012, s. 97; Sladek } \\
\text { ve Grabinger, 2013, s. } 11\end{array}$ \\
\hline Görsel olarak öğrenme & Sladek ve Grabinger, 2013, s. 11 \\
\hline Liderlik becerisi & Sladek ve Grabinger, 2013, s. 1 \\
\hline Esnek & Mishra, 2012, s.97; Schawbel, 2014, s. 7 \\
\hline $\begin{array}{llll}\begin{array}{l}\text { Farklı kültürlere } \\
\text { toleransl1) }\end{array} & \text { hoşgörülü } & \text { (çeşitliliğe karş1 } \\
\end{array}$ & $\begin{array}{l}\text { Tabscott, 2009, s. 6; Mishra, 2012, s. 97; Schawbel, } \\
2014 \text {, s. } 7\end{array}$ \\
\hline Açık görüşlü & Schawbel, 2014, s. 9 \\
\hline Hizlı hareket etme & $\begin{array}{l}\text { Tabscott, } 2009 \text {, s. } 7 \text {; Levickaite, } 2010, \text { s. } 173 \text {; } \\
\text { Rothman, 2014, s. } 5\end{array}$ \\
\hline Daha fazla üretme & Rothman, 2014, s. 5 \\
\hline Sosyal ağlara önem verme & Mishra, 2012, s. 96 \\
\hline Bağımsız & Tabscott, 2009, s. 6; Mishra, 2012, s. 97 \\
\hline Akilli & Tabscott, 2009, s. 6; Mishra, 2012, s. 97 \\
\hline İşbirliği & Tabscott, 2009, s. 7 \\
\hline Bireyci & Tabscott, 2009, s. 7 \\
\hline Eğlence & Tabscott, 2009 , s. 7 \\
\hline Araştırma & Tabscott, 2009, s. 7 \\
\hline Dürüstlük & Tabscott, 2009, s. 7 \\
\hline Yenilik & Tabscott, 2009 , s. 7 \\
\hline Küresel olarak bağlı & Schawbel, 2014, s. 7 \\
\hline \multicolumn{2}{|c|}{$\begin{array}{l}\text { Sladek ve Grabinger'e }(2013 \text {, s. 7) göre } Z \text { kuşağ1, önceki nesillere göre çok farklı bir çevre } \\
\text { tarafından şekillendirilmiştir; ekonomi, teknoloji, toplum ve ebeveynlik bu kuşağ1 etkilemede } \\
\text { büyük rol oynamıştır. }\end{array}$} \\
\hline
\end{tabular}


Yazarlara göre $Z$ kuşağı bireyleri iyi çalışanlardır ancak işletmeler $Z$ kuşağı bireylerini anlamazlar ise onları işe almak ve yönetmek konusunda zorluk çekebilirler. Dolayısıyla işletmelerin söz konusu kuşağın bireylerinin nasıl çalıştıklarını ve onların nasıl adapte olduklarını öğrenmeleri gerekmektedir. Sladek ve Grabinger (2013, s. 12-13) tarafından işletmelere bu konuda aşağıda yer alan birtakım öneriler sunulmuştur:

Dijital bir varlık oluşturun: $Z$ kuşağına göre, fiziksel ve sanal dünyalar arasında bir ayrım yoktur. Bir şirket çevrimiçi ortamda aktif değilse, kuruluşun da var olmadığını varsayarlar. $Z$ kuşağının çevrimiçi olduğu yerde şirketlerin aktif olması gerekir. Gençlerin Facebook ve Twitter gibi geleneksel sosyal medya sitelerinden uzaklaştığı söylentilerine rağmen araştırmalar tam tersini göstermiştir. JWT Intelligence'a göre, 8 ila 17 yaşları arasındakilerin \% 65'inin Facebook ve \% 26'sının bir Twitter profili vardır. İşletmelerin Instagram, SnapChat, Kik ve YouTube gibi genç kullanıcı yoğunluğuna sahip ağların yanı sıra bu geleneksel sitelerdeki $Z$ kuşağı bireylerine de ulaşmaları gerekmektedir.

Onlara söz verin: $Z$ kuşağı duyulmayı bekler ve ister. Onlar yetişkinlerle bir araya gelebilecekleri, fikirlerini duyurabilecekleri ve düşünebilecekleri ve fark yaratmaya yardımc1 olacakları bir yer isterler. $Z$ kuşağını dinleyen ve projelere gerçekten katkıda bulunmalarına izin veren şirketler, bu kuşak tarafından büyük bir sadakat ve saygı kazanacaklardır.

Topluluk taahhüdü yapın: $Z$ kuşağı dünyayı değiştirme motivasyon ve becerisine, şirketler ise bunu yapacak kaynaklara sahiptir. $Z$ kuşağı, çalışanlara bir fark yaratmalarına yardımcı olmak için içgörü sağlama ve yatırım yapma konusunda etkili olmaya özen gösteren şirketleri sever.

Mobil cihazlarla bağlanın (bağlantı sağlayın): Z kuşağı çalısanlarına hitap etmek isteyen şirketlerin geleneksel pazarlamanın ötesine geçmesi ve mobil pazarlamaya odaklanması gerekiyor - geleneksel pazarlama $Z$ kuşağına ulaşmiyor.

Esnek zamanlama sunun: $Y$ kuşağına çok benzer şekilde, $Z$ kuşağı da çalışmak için yaşamıyor. Sağlıklı bir iş-yaşam dengesi onlar için sadece bir beklenti değil, aynı zamanda bir gerekliliktir. Şirketlerin bu ihtiyacı karşılamasının en kolay yollarından biri çalışanların evden çalışmalarına izin vermektir.

Yapı sağlayın: İstedikleri zaman çalışma özgürlüğüne sahip olmak isteyen $Z$ kuşağının, ne için çalışacaklarını bilmeleri gerekir. Şiddetli rekabet, helikopter ebeveynler ve sistematik eğitim, Z kuşağının yapı istemesine neden olmuştur. "Free-Range Kids: Giving Our Children the Freedom We Had Without Going Nuts with Worry," yazarı Lenore Skenazy, yapı eksikliğinin Z kuşağını korkuttuğunu paylaşmıştır. Onlar, çalışmak için bir hedefleri olduğunda daha verimli çalışırlar.

Otoritenin önemsizliğini kabul edin: $Z$ kuşağı için otorite önemsizdir. Onlar, herkesin görüşünün dikkate almaya değer olduğunu ve herkesin eşit olduğunu öğrenerek büyüdüler. $Z$ kuşağının çoğunluğu ebeveynlerini en iyi arkadaşları olarak görür. Birçok okul, öğrencilerini öğretmenlerini ilk isimleri ile çağırmaya teşvik eder. Hatta bu kuşağın bireyleri Twitter üzerinden günlük olarak polisler ve hükümet yetkilileri ile ilgilenirler. İşletmeler bu kayıtsızlı̆ın bir meydan okuma eylemi olmadığını anlamalıdır; onlar herhangi biri ile işbirliği yapmak ve çalışmak için isteklidir.

Geribildirim sağlayın: $Z$ kuşağı için üç aylık hatta yıllık incelemeler yeterli olmayacaktır. Onlara anında sonuç veren oyun ve oyuncaklarla büyüdükten sonra, bu nesil sürekli ve anında geribildirim ister. $\mathrm{Bu}$ olumsuz bir nitelik gibi görünse de öyle değildir. Onlar ben merkezli oldukları için değil çalışmalarının başarısını değerlendirmek istedikleri için geribildirim isterler. 
Neyin işe yaradığını, neyin işe yaramadığını ve daha iyisini yapabilmek için neye ihtiyaçları olduğunu bilmek isterler. Sonuçlar daha anlamlı gelirse $Z$ kuşağı gönüllü olarak değişim arar.

Çalışma ekipleri oluşturun: $Z$ kuşağı bireyleri tüm hayatlarını işbirliği içinde geçirirler. Onların tüm fikirlerini aile, arkadaş ve internet üzerinde onlar gibi düşünen yabancılar şekillendirir ve yardıma ihtiyaç duyduklarında çevrimiçi topluluklarına ulaşırlar. İşyerinde de, aynı taktiklere güveneceklerdir. $Z$ kuşağı işçilerini kilit noktalara yerleştiren işletmeler, neslin gerçek potansiyelinden faydalanacaklardır.

Öğretme davranışına yatırım yapın: Z kuşağının kişiler arası becerilerden yoksun olduğu belgelenmiştir; isteksiz öğrenciler değillerdir, sadece hayatta kalma becerilerine ihtiyaç duymamışlardır. Bu nesil, her şey için teknolojiye güvenme konusundaki doğal eğilimleriyle mücadele etmek için müşteri hizmetleri ve kişiler arası ilişkilerde sürekli rehberliğe ihtiyaç duyacaktır. Daha önce belirtildiği gibi, Z kuşağına öğretmenin en iyi yolu ders tarzı konferanslar değildir; bunun yerine şirketlerin $Z$ kuşağ issçilerini bir mentor ile eşleştirmeleri gerekir. Mentorlük işyerinde kuşaksal boşlukların kapatılmasına yardımcı olur ve hem mentör hem de ders alan kişi birbirinden öğrenebilir.

$Y$ ve $Z$ kuşakları arasında bir takım farklılıklar kadar benzerliklerin de söz konusu olduğu gözlemlenmektedir. Her iki nesil de bağımsızlığına önem veren, açık görüşlü, akıllı, hızlı hareket eden, farklı kültürlere hoşgörülü, finansal açıdan bilinçli, işbirlikçi olmakla birlikte her iki nesil de teknoloji içinde büyümüş bir nesildir. Y ve $Z$ kuşağı arasındaki benzerlik ve farklılıkların iş hayatına da yansıyacağı düşünülmektedir. Dolayısıyla yukarıda çizilen kavramsal çerçeve sonucunda araştırmada aşağıda yer alan araştırma sorularına yanıt aranmaktadır:

1. $Y$ ve $Z$ kuşağının iş yaşamından beklentileri arasında ne tür benzerlikler/farklılıklar vardır?

1.1. $Y$ ve $Z$ kuşağının iş yaşamından örgüt kültürü açısından beklentileri arasında ne tür benzerlikler/farklılıklar vardır?

1.2. $Y$ ve $Z$ kuşağının iş yaşamından lider açısından beklentileri arasında ne tür benzerlikler/farklılıklar vardır?

1.3. $Y$ ve $Z$ kuşağının iş yaşamından iletişim açısından beklentileri arasında ne tür benzerlikler/farklılıklar vardır?

1.4. $Y$ ve $Z$ kuşağının iş yaşamından karar verme açısından beklentileri arasında ne tür benzerlikler/farklılıklar vardır?

1.5. $Y$ ve $Z$ kuşağının iş yaşamından takım çalışması açısından beklentileri arasında ne tür benzerlikler/farklılıklar vardır?

1.6. $Y$ ve $Z$ kuşağının iş yaşamından motivasyon açısından beklentileri arasında ne tür benzerlikler/farklılıklar vardır?

1.7. $Y$ ve $Z$ kuşağının iş yaşamından gelişme açısından beklentileri arasında ne tür benzerlikler/farklılıklar vardır?

\section{ARAŞTIRMANIN AMACI VE ÖNEMİ}

$\mathrm{Bu}$ araştırmanın esas amacı $\mathrm{Y}$ ve $Z$ kuşaklarının iş hayatından kültür, yönetici, iletişim, karar verme, takım çalışması, motivasyon ve gelişim konularında beklentilerinin neler olduğunu belirlemektir. Diğer bir ifade ile çalışmada hem Y kuşağının hem de şu anda üniversitede eğitimine devam eden ya da iş hayatına yeni girmekte olan $Z$ kuşağının iş hayatından beklentilerinin neler olduğunun belirlenmesi, söz konusu her iki kuşağın beklentilerinin karşılaştırılması, benzerlik ve farklılıkların belirlenmesi ve her iki kuşağın üst düzey yöneticilerine kuşakların beklentileri konusunda 1 şı tutulması amacı benimsenmiştir. Böylelikle işletme üst düzey yöneticileri kuşaklar arasındaki benzerlik ve farklılıklar ve birlikte 
çalıştığ kuşağa göre hangi konulara daha çok önem vermesi gerektiği konularında bilgi sahibi olabilecektir.

Literatür taraması yapıldığında özellikle $Z$ kuşağının iş hayatından beklentisine dair tek bir çalışmanın varlığına rastlanmış olmakla birlikte $Y$ ve $Z$ kuşaklarının iş hayatından beklentilerinin karşılaştırılıp, farklılıklarının belirlenmesine yönelik herhangi bir çalışmanın varlığına rastlanılmamıştır. Bu nedenle söz konusu çalışma Türkiye'de her iki kuşağın beklentilerini belirleyip karşılaştırma konusunda yapılan ilk çalışma özelliğini taşımaktadır. Çalışmanın önemi de buradan kaynaklanmaktadır.

\section{ARAŞTIRMANIN YÖNTEMI}

\section{1. Örneklem}

Araştırmanın evrenini, 2019-2020 Eğitim-Öğretim yılında Gümüşhane Üniversitesi'nde öğrenim gören ve 1981-2000 ve 2000 yılı sonrasında doğmuş olan Y ve Z kuşakları arasında yer alan lisans öğrencileri oluşturmaktadır. Araştırmanın örneklemini ise seçkisiz olmayan örnekleme yöntemlerinden biri olan kolayda örnekleme yöntemi ile seçilen 171 kadın 179 erkek olmak üzere toplam 350 öğrenci oluşturmaktadır. Etik Kurul Onayı: Gümüşhane Üniversitesi Bilimsel Araştırma ve Yayın Etiği Kurulu'nun 2020/4 sayı ve 07.04.2020 tarihli toplantısında görüşülmüş ve kabul edilmiştir.

Araştırmaya katılmayı kabul eden öğrencilerin kişisel bilgileri Tablo 6’da yer almaktadır.

Tablo 6. Araştırmaya Katılan Öğrencilere Ait Demografik Bilgiler

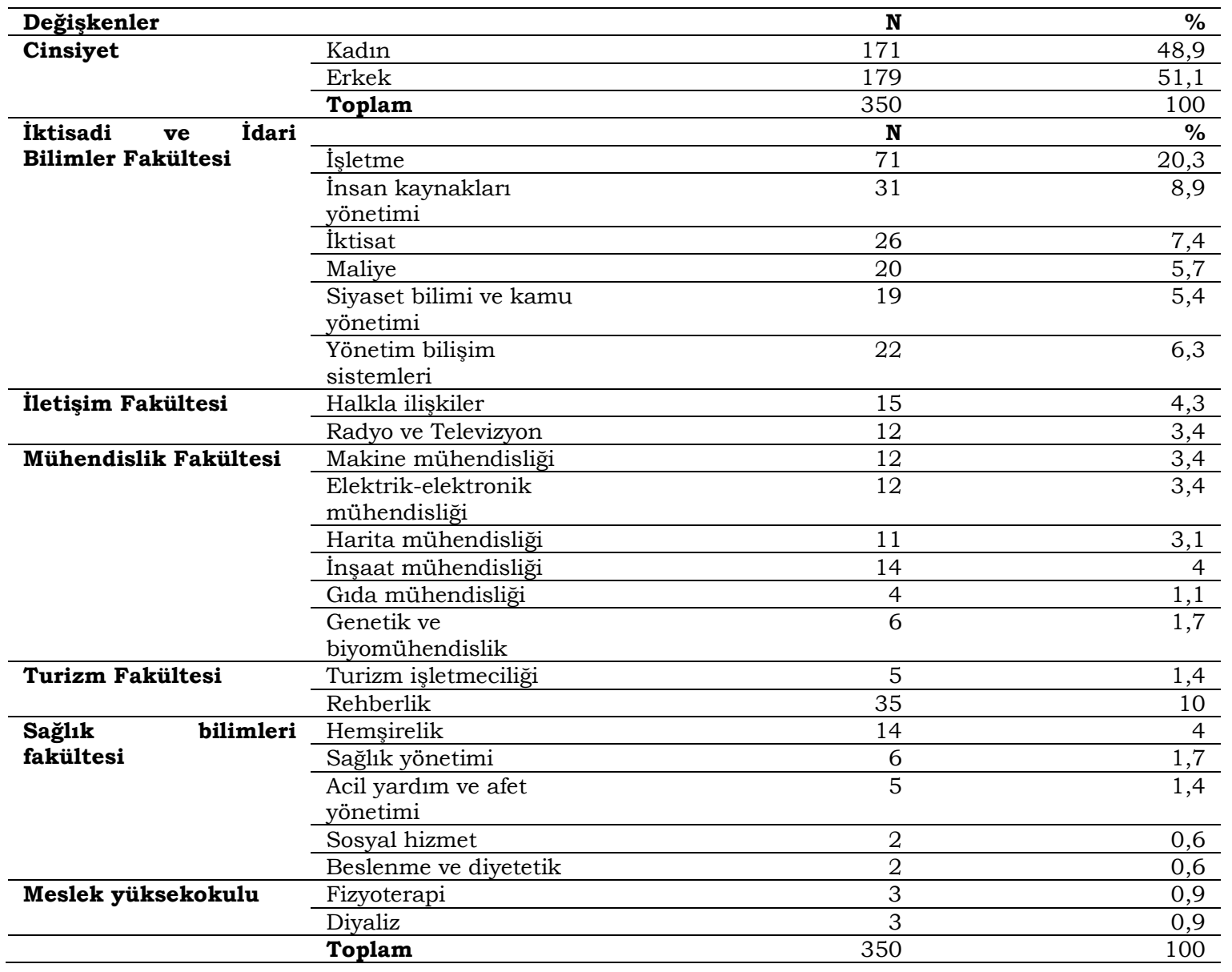


Tablo 6’ya göre, araştırmaya katılan öğrencilerin demografik özellikleri incelendiğinde, katılımcıların \%51,1'ini erkeklerin \%48,9'unu ise kadınların oluşturduğu görülmektedir. Bununla birlikte araştırmaya katılan öğrencilerin en fazla işletme $(\% 20,3)$ ve rehberlik $(\% 10)$ bölümünde okudukları görülmektedir.

Örneklemin yeterliliğinin belirlenebilmesi için Kaiser-Meyer-Olkin (KMO) testi yapılmıştır. Büyüköztürk (2007)'e göre KMO örneklem yeterlilik indeksinin \%60'dan yüksek olmas1 gerekmektedir. Çalışmada ise KMO değeri, örneklem yeterliliğinin iyi düzeyde olduğunu gösteren 0,914 olarak bulunmuştur.

\subsection{Analiz ve Testler}

Çalışmada Jusoh, M., Simun, M. ve Chong, S.C. (2011) tarafından geliştirilen ve yeni mezun olan çalışanların mevcut durum ile beklentileri arasındaki farkın örgütsel bağlılı̆ga ve iş tatminine etkilerinin incelendiği makalede yer alan değişkenler Türkçeye çevrilmiş ve anket formu Gümüşhane Üniversitesi öğrencilerine uygulanmıştır. Anket formu iki kısımdan oluşmakta olup birinci bölüm katılımcıların demografik özelliklerini ikinci bölüm ise katılımcıların iş hayatından beklentilerini belirlemeye yönelik soruları içermektedir. Ayrıca anket formu örgüt kültürü, yönetici, iletişim, karar verme, takım çalışması, motivasyon ve gelişme olmak üzere 7 faktörden oluşmuştur. Çalışmada hangi test türünün uygulanacağını belirleyebilmek amacıyla normallik analizi uygulanmış olup verilerin normal dağılıp dağılmadığını test edebilmek için çarpıklık (skewness) ve basıklık (kurtosis) değerlerine bakılmıştır. Tablo 7'de çarpıklık ve basıklık değerlerine yer verilmiştir.

Tablo 7. Çarpıklık ve Basıklık Değerleri

\begin{tabular}{lrr}
\hline Değişkenler & Çarp1klık (skewness) & Basıklık (kurtosis) \\
\hline Örgüt kültürü & $-1,357$ & 1,515 \\
\hline Lider & $-1,138$ & 1,285 \\
\hline İletişim & $-1,054$ & 1,503 \\
\hline Karar verme & 0,872 & 0,944 \\
\hline Takım çalışması & $-0,776$ & 0,601 \\
\hline Motivasyon & $-1,345$ & 1,502 \\
\hline Gelişim & $-1,529$ & 2,419 \\
\hline
\end{tabular}

Şencan (2002)'a göre çarpıklık ile basıklık değerleri $-2 \leq X \leq 2$ arasında yer alıyorsa verilerin normal dağıldığı söylenebilmektedir. Kalaycı (2008)'ya göre ise çarpıklık ve basıklık değerlerinin -3 ile +3 arasında yer alması normal dağıldığına işaret etmektedir. Tablo 7'ye göre verilerin normal dağıldıkları varsayılmıştır.

Daha sonra araştırmada kullanılan ölçeklerin, güvenilirlikleri Cronbach's Alpha yöntemi kullanılarak test edilmiş olup araştırmada kullanılan ölçeğin güvenilirlik değeri Cronbach's Alpha 0,965 olarak bulunmuş olup söz konusu değer $0,60 \leq a<0,80$ aralığında olduğu için ölçeklerin oldukça güvenilir olduğu söylenilebilmektedir (Kalayc1, 2008, s. 405).

Alfa güvenirlik testine göre güvenilirlikleri ispatlanan değişkenler için sorulan sorular SPSS’te "compute variable" seçeneği ile birleştirilmiş ve karşılaştırma analizlerine elverişli olan araştırma değişkenleri oluşturulmuş ve tanımlayıcı istatistiklere ait veriler tablo 8'de sunulmuş ardından da bağımsız gruplar t testi yapılmıştır. 
Tablo 8. Tanımlayıcı İstatistikler

\begin{tabular}{lrrrr}
\hline & & Y kuşağ & Z kuşă̆1 \\
\hline Örgüt kültürü & 4,1133 & 0,83506 & Ortalama & Standart sapma \\
\hline Lider & 3,8848 & 0,89158 & 4,0114 & 0,90278 \\
\hline İletişim & 3,6238 & 0,77779 & 3,9133 & 0,85729 \\
\hline Karar verme & 3,7524 & 0,82522 & 3,7010 & 0,75394 \\
\hline Takım çalișmas1 & 3,7000 & 0,81238 & 3,7590 & 0,73687 \\
\hline Motivasyon & 4,1333 & 0,90691 & 3,6848 & 0,81031 \\
\hline Gelişim & 4,1352 & 0,90908 & 4,1819 & 0,88810 \\
\hline
\end{tabular}

Tablo 8'deki analiz sonucuna göre Y kuşağ1 bireylerinin örgüt kültürü ifadelerine verdikleri yanıtların ortalamasına göre beklentileri 4,11 iken $Z$ kuşağı bireylerinin 4,01'dir. Bu da likert ölçeğine örgüt kültüründen beklentilerin “önemli” olduğu sonucunu göstermektedir. Bunun gibi diğer ölçek ifadelerinin de verilen yanıtlara göre önemli olduğu sonucuna ulaşılmış olup her bir ifadeden beklentileri ölçmek amacıyla kişilere sorulan ifadeler ayrı ayrı incelenmiştir.

Tablo 9. Bağımsız Gruplar T-Testi (Levene Test)

\begin{tabular}{|c|c|c|c|c|c|c|c|}
\hline & $\mathbf{F}$ & $\mathbf{P}$ & $\mathbf{T}$ & Df & tailed) & $\begin{array}{r}\text { Ortalamalar } \\
\text { aras1 fark }\end{array}$ & $\begin{array}{l}\text { Fark } \\
\text { S.H. }\end{array}$ \\
\hline \multirow[t]{2}{*}{ Örgüt kültürü } & 0,622 & 0,431 & $-1,096$ & 348 & 0,274 & $-0,10190$ & 0,09296 \\
\hline & & & $-1,096$ & 345,906 & 0,274 & $-0,10190$ & 0,09296 \\
\hline \multirow[t]{2}{*}{ Lider } & 0,090 & 0,764 & 0,306 & 348 & 0,760 & 0,02857 & 0,09350 \\
\hline & & & 0,306 & 347,466 & 0,760 & 0,02857 & 0,09350 \\
\hline \multirow[t]{2}{*}{ İletişim } & 0,403 & 0,526 & 0,942 & 348 & 0,347 & 0,07714 & 0,08188 \\
\hline & & & 0,942 & 347,663 & 0,347 & 0,07714 & 0,08188 \\
\hline \multirow[t]{2}{*}{ Karar verme } & 0,431 & 0,512 & 0,080 & 348 & 0,937 & 0,00667 & 0,08363 \\
\hline & & & 0,080 & 343,631 & 0,937 & 0,00667 & 0,08363 \\
\hline \multirow[t]{2}{*}{ Takım çalışması } & 0,250 & 0,618 & $-0,176$ & 348 & 0,861 & $-0,01524$ & 0,08674 \\
\hline & & & $-0,176$ & 347,998 & 0,861 & $-0,01524$ & 0,08674 \\
\hline \multirow[t]{2}{*}{ Motivasyon } & 0,112 & 0,738 & 0,506 & 348 & 0,613 & 0,04857 & 0,09595 \\
\hline & & & 0,506 & 347,847 & 0,613 & 0,04857 & 0,09595 \\
\hline \multirow[t]{2}{*}{ Gelişme } & 0,043 & 0,836 & 0,219 & 348 & 0,826 & 0,02095 & 0,09551 \\
\hline & & & 0,219 & 347,563 & 0,826 & 0,02095 & 0,09551 \\
\hline
\end{tabular}

P (2-tailed) sütunundaki verilerin 0,05'den küçük olması durumu Y ve $Z$ kuşakları arasında anlamlı bir farklılık olduğunu, 0,05'den büyük olması ise Y ve $Z$ kuşakları arasında anlamlı farklılıklar olmadığını göstermektedir. Tablo 9'daki sonuçlara göre bütün boyutların verilerinin 0,05'den büyük olması sebebi ile $\mathrm{Y}$ ve $Z$ kuşakları arasında anlamlı farklılıklar olmadığ sonucuna ulaşılmıştır.

Bağımsız gruplar t testinden sonra $Y$ ve $Z$ kuşaklarının her bir boyut açısından hangi maddelere daha fazla önem verdiğini anlayıp karşılaştırma yapabilmek amacıyla soruların frekans analizine bakılmıştır.

\section{BULGULAR}

Araştırmada Y ve $Z$ kuşağı bireylerine iş hayatından beklentilerini ölçümlemek amacı ile sorular yönetilmiştir. Yapılan analiz sonuçlarına göre bulgular aşağıda yer alan tablolarda özetlenmektedir. 
Tablo 10. Y ve $Z$ kuşağının İş hayatında Örgüt Kültüründen Beklentileri

\begin{tabular}{|c|c|c|c|c|c|c|c|}
\hline Y Kuşağının Örgüt Kültüründen Beklentileri & $\begin{array}{c}1 \\
\% \\
\mathrm{~N}\end{array}$ & $\begin{array}{c}\mathbf{2} \\
\% \\
\mathrm{~N}\end{array}$ & $\begin{array}{r}3 \\
\% \\
\mathrm{~N}\end{array}$ & $\begin{array}{c}\mathbf{4} \\
\% \\
\mathrm{~N}\end{array}$ & $\begin{array}{r}\mathbf{5} \\
\% \\
\mathrm{~N}\end{array}$ & $\bar{x}$ & $\mathbf{S}$ \\
\hline 1- İșletmede çalışanlar birbirlerine değer vermeli. & 5,7 & 3,4 & 6,3 & 26,3 & 58,3 & 4,28 & 1,107 \\
\hline $\begin{array}{l}\text { 2- İşletme, müssterilerini dinlemeli ve onların } \\
\text { gereksinimlerine hızlı yanıt vermeli. }\end{array}$ & 3,4 & 1,7 & 12,6 & 22,9 & 59,4 & 4,33 & 0,9964 \\
\hline $\begin{array}{l}\text { 3- İşletme, her zaman işletmede olup bitenleri } \\
\text { çalşsanları ile paylaşmalı. }\end{array}$ & 5,7 & 8,6 & 28,0 & 30,3 & 27,4 & 3,65 & 1,139 \\
\hline $\begin{array}{l}\text { 4- İşletme, çalışanlarının daha verimli olabilmesi için } \\
\text { daima yollar aramalı. }\end{array}$ & 4,0 & 3,4 & 12,6 & 30,3 & 49,7 & 4,18 & 1,045 \\
\hline 5- Çalışanlar, takım halinde uyumlu çalışmalı. & 2,3 & 5,1 & 13,1 & 27,4 & 52,0 & 4,21 & 1,010 \\
\hline $\begin{array}{l}\text { 6- İşletme, çalışanlarının herhangi bir kissisel } \\
\text { probleminin üstesinden gelebilmesi için çözüm aramalı. }\end{array}$ & 4,0 & 6,9 & 12,6 & 36,6 & 40,0 & 4,01 & 1,079 \\
\hline Z Kuşağının Örgüt Kültüründen Beklentileri & $\begin{array}{c}1 \\
\% \\
\mathrm{~N}\end{array}$ & $\begin{array}{c}\mathbf{2} \\
\% \\
\mathrm{~N}\end{array}$ & $\begin{array}{c}3 \\
\% \\
\mathrm{~N}\end{array}$ & $\begin{array}{c}\mathbf{4} \\
\% \\
\mathrm{~N}\end{array}$ & $\begin{array}{r}\mathbf{5} \\
\% \\
\mathrm{~N}\end{array}$ & $x^{-}$ & $\mathbf{S}$ \\
\hline 1- İşletmede çalışanlar birbirlerine değer vermeli. & 9,7 & 2,9 & 11,4 & 25,7 & 50,3 & 4,04 & 1,270 \\
\hline $\begin{array}{l}\text { 2- İşletme, müşterilerini dinlemeli ve onların } \\
\text { gereksinimlerine hızlı yanıt vermeli. }\end{array}$ & 3,4 & 8,0 & 8,0 & 32,6 & 48,0 & 4,13 & 1,084 \\
\hline $\begin{array}{l}\text { 3- İssletme, her zaman işletmede olup bitenleri çalışanları } \\
\text { ile paylaşmal.. }\end{array}$ & 5,1 & $\begin{array}{r}10 \\
3\end{array}$ & 33,1 & 23,4 & 28,0 & 3,58 & 1,150 \\
\hline $\begin{array}{l}\text { 4- İssletme, çalışanlarının daha verimli olabilmesi için } \\
\text { daima yollar aramalı. }\end{array}$ & 4,6 & 5,7 & 10,3 & 31,4 & 48,0 & 4,12 & 1,101 \\
\hline 5- Çalışanlar, takım halinde uyumlu çalışmalı. & 6,3 & 5,1 & 15,4 & 17,7 & 55,4 & 4,10 & 1,215 \\
\hline $\begin{array}{l}\text { 6- İşletme, çalışanlarının herhangi bir kişisel } \\
\text { probleminin üstesinden gelebilmesi için çözüm aramall. }\end{array}$ & 2,9 & 4,6 & 17,7 & 32,6 & 42,3 & 4,06 & 1,020 \\
\hline
\end{tabular}

Tablo 10'a göre Y kuşağ bireyleri işletmenin müşterileri dinlemesi ve onların gereksinimlerine hızlı yanıt vermesi gerektiğine vurgu yapmaktadır. Tablo 10'daki dağılıma bakıldığında bu ifade 4,33’lük bir ortalama ile en yüksek ortalamaya sahiptir. Aynı şekilde $Z$ kuşağı bireyleri için de 4,13’lük en yüksek ortalama ile işletmenin müşterilerini dinlemesi ve gereksinimlerine hızlı yanıt vermesi önem taşımaktadır. Y kuşağı için ikinci sırada önemli olarak vurgulanan işletmede çalışanların birbirlerine değer vermesi $(4,28)$ iken $Z$ kuşağı için önemli olan işletme çalışanlarının daha verimli olabilmesi için daima yeni yollar aranması $(4,12)$ gerektiğidir. Y kuşağı bireyleri ayrıca çalışanların takım halinde uyumlu çalışması ve işletmenin, çalışanların daha verimli olabilmesi için daima yollar araması gerektiğinin önemine değinirken $Z$ kuşağı da çalışanların takım halinde uyumlu çalışmasının ve işletmenin, çalışanlarının herhangi bir kişisel probleminin üstesinden gelebilmesine yardımcı olması gerekliliğine vurgu yapmışlardır. Her iki kuşağın bireyleri de işletmede olup bitenlerin çalışanlar ile paylaşılmasının çok önemli olmadığını vurgulamıştır.

Tablo 11. Y ve $Z$ kuşağının İş hayatında Liderden Beklentileri

\begin{tabular}{|c|c|c|c|c|c|c|c|}
\hline Y Kuşağının Liderden Beklentileri & $\begin{array}{r}1 \\
\% \\
\mathrm{~N}\end{array}$ & $\begin{array}{c}\mathbf{2} \\
\% \\
\mathrm{~N}\end{array}$ & $\begin{array}{l}3 \\
\\
\% \\
\mathrm{~N}\end{array}$ & $\begin{array}{r}\mathbf{4} \\
\% \\
\mathrm{~N}\end{array}$ & $\begin{array}{r}\mathbf{5} \\
\% \\
\mathrm{~N}\end{array}$ & $\bar{x}$ & $\mathbf{S}$ \\
\hline 1- Yöneticim benim için rol model olmalı. & 6,9 & 6,9 & 23,4 & 33,7 & 29,1 & 3,71 & 1,158 \\
\hline $\begin{array}{l}\text { 2- Yöneticim yapılması gerekenleri yaptığımda ne elde } \\
\text { edeceğimi açıkça belirtmeli. }\end{array}$ & 3,4 & 8,6 & 17,1 & 40,6 & 30,3 & 3,85 & 1,054 \\
\hline $\begin{array}{l}\text { 3- Yöneticim gelecekte karşılaşabileceğim firsatlara } \\
\text { göre bir vizyon oluşturmall. }\end{array}$ & 4,0 & 5,7 & 17,1 & 37,7 & 35,4 & 3,94 & 1,057 \\
\hline $\begin{array}{l}\text { 4- Yöneticim düzeltilmesi gereken hatalar için } \\
\text { performansımı izlemeli. }\end{array}$ & 5,1 & 6,3 & 13,7 & 42,3 & 32,6 & 3,90 & 1,084 \\
\hline $\begin{array}{l}\text { 5- Yöneticim çabalarımın karşılığında } \\
\text { ödüllendirilebilmem için ne yapmam gerektiğini } \\
\text { söylemeli. }\end{array}$ & 4,6 & 8,0 & 17,1 & 38,3 & 32,0 & 3,85 & 1,098 \\
\hline $\begin{array}{l}\text { 6- Yöneticim standartlara uymayan durumlarda beni } \\
\text { uyarmall. }\end{array}$ & 5,7 & 4,0 & 13,1 & 36,0 & 41,1 & 4,02 & 1,106 \\
\hline
\end{tabular}


Tablo 11. Y ve Z kuşağının İş hayatında Liderden Beklentileri (Devamı)

\begin{tabular}{|c|c|c|c|c|c|c|c|}
\hline Z Kuşağının Liderden Beklentileri & $\begin{array}{r}1 \\
\% \\
\mathrm{~N} \\
\end{array}$ & $\begin{array}{r}\mathbf{2} \\
\% \\
\mathrm{~N} \\
\end{array}$ & $\begin{array}{r}3 \\
\% \\
\mathrm{~N} \\
\end{array}$ & $\begin{array}{c}4 \\
\% \\
\mathrm{~N} \\
\end{array}$ & $\begin{array}{r}\mathbf{5} \\
\% \\
\mathrm{~N} \\
\end{array}$ & $\bar{x}$ & $\mathbf{S}$ \\
\hline 1- Yöneticim benim için rol model olmalı. & 5,7 & 10,3 & 16,6 & 37,7 & 29,7 & 3,75 & 1,155 \\
\hline $\begin{array}{l}\text { 2- Yöneticim yapılması gerekenleri yaptığımda ne elde } \\
\text { edeceğimi açıkça belirtmeli. }\end{array}$ & 3,4 & 8,6 & 13,1 & 36,6 & 38,3 & 3,97 & 1,082 \\
\hline $\begin{array}{l}\text { 3- Yöneticim gelecekte karşılaşabileceğim firsatlara } \\
\text { göre bir vizyon oluşturmall. }\end{array}$ & 5,1 & 3,4 & 14,3 & 37,7 & 39,4 & 4,02 & 1,069 \\
\hline $\begin{array}{l}\text { 4- Yöneticim düzeltilmesi gereken hatalar için } \\
\text { performansımı izlemeli. }\end{array}$ & 6,3 & 5,1 & 20,0 & 32,0 & 36,6 & 3,87 & 1,152 \\
\hline $\begin{array}{l}\text { 5- Yöneticim çabalarımın karşılığında } \\
\text { ödüllendirilebilmem için ne yapmam gerektiğini } \\
\text { söylemeli. }\end{array}$ & 3,4 & 4,6 & 21,7 & 42,3 & 28,0 & 3,86 & 0,9883 \\
\hline $\begin{array}{l}\text { 6- Yöneticim standartlara uymayan durumlarda beni } \\
\text { uyarmall. }\end{array}$ & 4,6 & 5,1 & 17,7 & 33,1 & 39,4 & 3,97 & 1,093 \\
\hline
\end{tabular}

Tablo 8'deki analiz sonucuna göre Y kuşağı bireylerinin lider ifadelerine verdikleri yanıtların ortalamasına göre beklentileri 3,88 iken $Z$ kuşağı bireylerinin 3,91'dir. Bununla birlikte Tablo 11 'e göre Y kuşağ bireylerinin liderden beklentileri içerisinde en yüksek ortalamaya sahip olan $(4,02)$ yöneticinin standartlara uymayan durumlarda çalışanı uyarmasıdır. $Z$ kuşağ bireyleri ise yöneticiden gelecekte karşılaşılabilecek firsatlara göre bir vizyon oluşturması beklentisi içerisindedir. Söz konusu gelecekte karş1laşılabilecek firsatlara göre yöneticinin bir vizyon oluşturması beklentisi Y kuşağı için ikinci sırada en önemli beklentiyi içerirken Z kuşağı için ikinci sırada en önemli beklentiyi hem yöneticinin standartlara uymayan durumlarda çalışanı uyarması $(3,97)$ hem de yapılması gerekenler yapıldığında çalışanın ne elde edeceğini açıkça belirtmesi $(3,97)$ içermektedir. Hem Y hem de Z kuşağının yöneticilerinden ortak beklentisi ise düzeltilmesi gereken hatalar için performans izlemesi yapması gerekliliğidir.

Tablo 12. Y ve $Z$ kuşağının İş hayatında İletişim Açısından Beklentileri

\begin{tabular}{|c|c|c|c|c|c|c|c|}
\hline Y Kuşağının İletişim Açısından Beklentileri & $\begin{array}{r}1 \\
\% \\
\mathrm{~N}\end{array}$ & $\begin{array}{c}2 \\
\% \\
\mathrm{~N}\end{array}$ & $\begin{array}{c}3 \\
\% \\
\mathrm{~N}\end{array}$ & $\begin{array}{c}\mathbf{4} \\
\% \\
\mathrm{~N}\end{array}$ & $\begin{array}{r}\mathbf{5} \\
\% \\
\mathrm{~N}\end{array}$ & $\overline{\mathbf{x}}$ & $\mathbf{S}$ \\
\hline $\begin{array}{l}\text { 1- Düşüncelerimi başkalarıyla özgürce } \\
\text { paylaşmalıyım. }\end{array}$ & 6,9 & 6,3 & 19,4 & 32,0 & 35,4 & 3,82 & 1,181 \\
\hline $\begin{array}{l}\text { 2- İnsanlarla konuşurken nazik ve yardımsever } \\
\text { olurum. }\end{array}$ & 9,7 & 1,1 & 12,6 & 34,9 & 41,7 & 3,97 & 1,212 \\
\hline 3- İnsanlarla sohbet etmekten keyif alırım. & 4,0 & 6,3 & 20,0 & 33,7 & 36,0 & 3,91 & 1,082 \\
\hline 4- Çoğunlukla aklıma ilk geleni söylerim. & 10,9 & 16,0 & 34,3 & 21,1 & 17,7 & 3,18 & 1,219 \\
\hline 5- İs arkadaşlarımın problemlerini dinlerim & 6,3 & 5,7 & 16,6 & 40,6 & 30,9 & 3,84 & 1,118 \\
\hline $\begin{array}{l}\text { 6- İş arkadaşlarıma çok uzun ve kesin talimatlar } \\
\text { veririm. }\end{array}$ & 16,6 & 17,1 & 29,7 & 23,4 & 13,1 & 2,99 & 1,266 \\
\hline Z Kuşağının İletişim Açısından Beklentileri & $\begin{array}{r}1 \\
\% \\
\mathrm{~N}\end{array}$ & $\begin{array}{r}2 \\
\% \\
\mathrm{~N}\end{array}$ & $\begin{array}{r}3 \\
\% \\
\mathrm{~N}\end{array}$ & $\begin{array}{r}4 \\
\% \\
\mathrm{~N}\end{array}$ & $\begin{array}{r}\mathbf{5} \\
\% \\
\mathrm{~N}\end{array}$ & $\overline{\mathbf{x}}$ & $\mathbf{S}$ \\
\hline $\begin{array}{l}\text { 1- Düşüncelerimi başkalarıyla özgürce } \\
\text { paylaşmalıyım. }\end{array}$ & 8,0 & 6,3 & 22,9 & 30,3 & 32,6 & 3,73 & 1,209 \\
\hline $\begin{array}{l}\text { 2- İnsanlarla konuşurken nazik ve yardımsever } \\
\text { olurum. }\end{array}$ & 4,0 & 5,7 & 13,1 & 33,1 & 44,0 & 4,07 & 1,077 \\
\hline 3- İnsanlarla sohbet etmekten keyif alırım. & 4,6 & 5,7 & 18,9 & 32,6 & 38,3 & 3,94 & 1,102 \\
\hline 4- Çoğunlukla aklıma ilk geleni söylerim. & 6,3 & 15,4 & 29,1 & 26,3 & 22,9 & 3,44 & 1,182 \\
\hline 5- İş arkadaşlarımın problemlerini dinlerim & 4,6 & 4,0 & 21,1 & 42,9 & 27,4 & 3,84 & 1,019 \\
\hline $\begin{array}{l}\text { 6- İş arkadaşlarıma çok uzun ve kesin talimatlar } \\
\text { veririm. }\end{array}$ & 6,3 & 25,1 & 27,4 & 27,4 & 13,7 & 3,17 & 1,141 \\
\hline
\end{tabular}

Tablo 8'deki analiz sonucuna göre Y kuşağı bireylerinin iletişim ifadelerine verdikleri yanıtların ortalamasına göre beklentileri 3,62 iken Z kuşağı bireylerinin 3,70'dir. İletişim boyutunun ifadelerini ayrı ayrı değerlendirdiğimizde ise insanlarla konuşurken nazik ve yardımsever olmanın önemli olduğunu belirten hem Y kuşağ hem de Z kuşağı bireyleri insanlarla sohbet etmekten keyif aldıklarını da belirtmişlerdir. Ayrıca her iki kuşağın bireyleri de iş arkadaşlarının 
problemlerini dinlediklerini belirtmiş ve düşüncelerini başkalarıyla özgürce paylaşabilmenin önemine değinmişlerdir.

Tablo 13. Y ve $Z$ kuşağının İş hayatında Karar Verme Açısından Beklentileri

\begin{tabular}{|c|c|c|c|c|c|c|c|}
\hline Y Kuşağının Karar Verme Açısından Beklentileri & $\begin{array}{c}1 \\
\% \\
\mathrm{~N}\end{array}$ & $\begin{array}{c}\mathbf{2} \\
\% \\
\mathrm{~N}\end{array}$ & $\begin{array}{c}3 \\
\% \\
\mathrm{~N}\end{array}$ & $\begin{array}{c}4 \\
\% \\
\mathrm{~N}\end{array}$ & $\begin{array}{r}\mathbf{5} \\
\% \\
\mathrm{~N}\end{array}$ & $\bar{x}$ & $\mathbf{S}$ \\
\hline $\begin{array}{l}\text { 1- Karar verirken içgüdülerime ve tepkilerime } \\
\text { güvenirim. }\end{array}$ & 10,9 & 5,7 & 23,4 & 29,7 & 30,3 & 3,62 & 1,270 \\
\hline $\begin{array}{l}\text { 2- Makul ve sistematik bir şekilde karar aldığımda } \\
\text { kendimi daha rahat hissederim. }\end{array}$ & 6,9 & 4,0 & 10,9 & 33,1 & 45,1 & 4,05 & 1,158 \\
\hline $\begin{array}{l}\text { 3- Karar alırken içgüdülerimden ziyade gerçekleri } \\
\text { dikkate alırım. }\end{array}$ & 5,7 & 5,1 & 24,0 & 34,3 & 30,9 & 3,79 & 1,110 \\
\hline $\begin{array}{l}\text { 4- Karar alırken kararın ardında mantıklı bir sebep } \\
\text { aramaktansa kararın doğru olduğunu hissetmeyi } \\
\text { tercih ederim. }\end{array}$ & 8,0 & 16,0 & 22,9 & 30,3 & 22,9 & 3,44 & 1,229 \\
\hline $\begin{array}{l}\text { 5- Veriler bir seçeneğin doğru olduğunu gösterseler } \\
\text { bile tam olarak inanmadığım bir konuda karar } \\
\text { vermem. }\end{array}$ & 4,0 & 11,4 & 23,4 & 33,7 & 27,4 & 3,69 & 1,112 \\
\hline $\begin{array}{l}\text { 6- Gerçek bilgilerin ayrıntılı analizine dayanarak } \\
\text { kararlar veririm. }\end{array}$ & 3,4 & 8,0 & 20,0 & 32,0 & 36,6 & 3,90 & 1,091 \\
\hline Z Kuşağının Karar Verme Açısından Beklentileri & $\begin{array}{r}1 \\
\% \\
\mathrm{~N}\end{array}$ & $\begin{array}{r}2 \\
\% \\
\mathrm{~N}\end{array}$ & $\begin{array}{r}3 \\
\% \\
\mathrm{~N}\end{array}$ & $\begin{array}{r}4 \\
\% \\
\mathrm{~N}\end{array}$ & $\begin{array}{r}\mathbf{5} \\
\% \\
\mathrm{~N}\end{array}$ & $\bar{x}$ & $\mathbf{S}$ \\
\hline $\begin{array}{l}\text { 1- Karar verirken içgüdülerime ve tepkilerime } \\
\text { güvenirim. }\end{array}$ & 8,6 & 9,1 & 20,0 & 32,6 & 29,7 & 3,69 & 1,383 \\
\hline $\begin{array}{l}\text { 2- Makul ve sistematik bir ssekilde karar aldığımda } \\
\text { kendimi daha rahat hissederim. }\end{array}$ & 2,9 & 6,9 & 16,6 & 39,4 & 34,3 & 3,95 & 1,021 \\
\hline $\begin{array}{l}\text { 3- Karar alırken içgüdülerimden ziyade gerçekleri } \\
\text { dikkate alırım. }\end{array}$ & 3,4 & 5,7 & 28,0 & 34,9 & 28,0 & 3,78 & 1,027 \\
\hline $\begin{array}{l}\text { 4- Karar alırken kararın ardında mantıklı bir sebep } \\
\text { aramaktansa kararın doğru olduğunu hissetmeyi } \\
\text { tercih ederim. }\end{array}$ & 7,4 & 12,6 & 27,4 & 33,1 & 19,4 & 3,44 & 1,157 \\
\hline $\begin{array}{l}\text { 5- Veriler bir seçeneğin doğru olduğunu gösterseler } \\
\text { bile tam olarak inanmadığım bir konuda karar } \\
\text { vermem. }\end{array}$ & 1,7 & 7,4 & 33,1 & 29,1 & 28,6 & 3,75 & 1,006 \\
\hline $\begin{array}{l}\text { 6- Gerçek bilgilerin ayrıntılı analizine dayanarak } \\
\text { kararlar veririm. }\end{array}$ & 4,0 & 4,0 & 21,7 & 36,6 & 33,7 & 3,92 & 1,036 \\
\hline
\end{tabular}

Tablo 8'deki analiz sonucuna göre hem Y hem de $Z$ kuşağı bireylerinin karar verme ifadelerine verdikleri yanıtların ortalamasına göre beklentileri 3,75'dir. Tablo 13'e göre her iki kuşağın bireylerinin de makul ve sistematik bir şekilde karar alırken kendilerini rahat hissettikleri, gerçek bilgilerin ayrıntılı analizine dayalı olarak karar verdikleri ve karar alma konusunda içgüdülerinden ziyade gerçekleri dikkate aldıkları sonucuna ulaşılmıştır.

Tablo 14. $Y$ ve $Z$ kuşağının İş hayatında Takım Çalışması Açısından Beklentileri

\begin{tabular}{|c|c|c|c|c|c|c|c|}
\hline $\begin{array}{l}\text { Y Kuşağının Takım Çalışması Açısından } \\
\text { Beklentileri }\end{array}$ & $\begin{array}{r}1 \\
\% \\
\mathrm{~N} \\
\end{array}$ & $\begin{array}{l}\mathbf{2} \\
\% \\
\mathrm{~N} \\
\end{array}$ & $\begin{array}{l}3 \\
\% \\
\mathrm{~N} \\
\end{array}$ & $\begin{array}{r}4 \\
\% \\
\mathrm{~N} \\
\end{array}$ & $\begin{array}{r}\mathbf{5} \\
\% \\
\mathrm{~N} \\
\end{array}$ & $\bar{x}$ & $\mathbf{S}$ \\
\hline $\begin{array}{l}\text { 1- Toplantılarda takımıma yön verme konusunda } \\
\text { sorumluluk alırım. }\end{array}$ & 8,0 & 8,0 & 19,4 & 37,1 & 27,4 & 3,68 & 1,189 \\
\hline $\begin{array}{l}\text { 2- Genellikle diğer ekip üyeleri arasında oluşan } \\
\text { anlaşmazlıkların çözülmesine yardımcı olurum }\end{array}$ & 4,0 & 8,0 & 18,9 & 44,6 & 24,6 & 3,77 & 1,034 \\
\hline $\begin{array}{l}\text { 3- Takımda olup biten hakkında herkesin haberdar } \\
\text { olmasını sağlarım. }\end{array}$ & 2,3 & 6,9 & 23,4 & 42,9 & 24,6 & 3,80 & 0,9631 \\
\hline $\begin{array}{l}\text { 4- Genellikle takımın tartışmayı nasıl organize } \\
\text { edeceğini belirlemesine yardımcı olurum. }\end{array}$ & 2,9 & 8,6 & 25,7 & 38,3 & 24,6 & 3,73 & 1,018 \\
\hline $\begin{array}{l}\text { 5- Toplantılarda takım arkadaşlarımın farklılıklarını } \\
\text { çözmelerine aktif olarak yardımcı olurum. }\end{array}$ & 3,4 & 9,1 & 21,7 & 44,6 & 21,1 & 3,70 & 1,011 \\
\hline $\begin{array}{l}\text { 6- Toplantıda konuşulan konularla ilgili not tutan kişi } \\
\text { olmaktan hoşlanırım. }\end{array}$ & 12,0 & 9,1 & 24,0 & 26,9 & 28,0 & 3,49 & 1,312 \\
\hline
\end{tabular}


Tablo 14. Y ve Z kuşağının İş hayatında Takım Çalışması Açısından Beklentileri (Devamı)

\begin{tabular}{lrrrrrrr}
\hline $\begin{array}{l}\text { Z Kuşağının Takım Çalışması Açısından } \\
\text { beklentileri }\end{array}$ & $\begin{array}{r}1 \\
\% \\
\mathrm{~N}\end{array}$ & $\begin{array}{r}\mathbf{2} \% \\
\mathrm{~N}\end{array}$ & $\begin{array}{r}\mathbf{3} \\
\mathrm{N}\end{array}$ & $\begin{array}{r}\mathbf{4} \\
\% \\
\mathrm{~N}\end{array}$ & $\begin{array}{r}\mathbf{5} \\
\mathrm{N}\end{array}$ & $\mathbf{x}$ & $\mathbf{S}$ \\
\hline $\begin{array}{l}\text { 1- Toplantılarda takımıma yön verme konusunda } \\
\text { sorumluluk alırım. }\end{array}$ & 7,4 & 6,3 & 22,9 & 38,9 & 24,6 & 3,66 & 1,136 \\
\hline $\begin{array}{l}\text { 2- Genellikle diğer ekip üyeleri arasında oluşan } \\
\text { anlassmazlıkların çözülmesine yardımcı olurum }\end{array}$ & 3,4 & 8,0 & 18,9 & 46,3 & 23,4 & 3,78 & 1,005 \\
\hline $\begin{array}{l}\text { 3- Takımda olup biten hakkında herkesin haberdar } \\
\text { olmasını sağlarım. }\end{array}$ & 4,0 & 12,0 & 24,0 & 32,6 & 27,4 & 3,67 & 1,120 \\
\hline $\begin{array}{l}\text { 4- Genellikle takımın tartışmayı nasıl organize } \\
\text { edeceğini belirlemesine yardımcı olurum. }\end{array}$ & 4,0 & 9,7 & 22,3 & 39,4 & 24,6 & 3,70 & 1,067 \\
\hline $\begin{array}{l}\text { 5- Toplantılarda takım arkadaşlarımın } \\
\text { farklılıklarını çözmelerine aktif olarak yardımcı } \\
\text { olurum. }\end{array}$ & 2,3 & 7,4 & 21,7 & 41,7 & 26,9 & 3,83 & 0,9831 \\
\hline $\begin{array}{l}\text { 6- Toplantıda konuşulan konularla ilgili not tutan } \\
\text { kişi olmaktan hoşlanırım. }\end{array}$ & 10,9 & 10,9 & 25,7 & 28,6 & 24,0 & 3,44 & 1,266 \\
\hline
\end{tabular}

Tablo 8'deki analiz sonucuna göre Y kuşağı bireylerinin takım çalışması ifadelerine verdikleri yanıtların ortalamasına göre beklentileri 3,70 iken Z kuşağı bireylerinin 3,68'dir. Tablo 14'e göre, Y kuşağı bireylerinin takım çalışması açısından en önemli beklentisi takımda olup biten hakkında herkesin haberdar olmasını sağlamak $(3,80)$ iken $Z$ kuşağı bireylerinin en önemli beklentisi toplantılarda takım arkadaşlarının farklılıklarını çözmelerine aktif olarak yardımcı olmaktır (3,83). Bununla birlikte hem Y hem de $Z$ kuşağ1 bireylerinin genellikle diğer ekip üyeleri arasında oluşan anlaşmazlıkların çözülmesine ve takımın tartışmayı nasıl organize edeceğini belirlemesine yardımcı olmayı tercih ettikleri sonucu elde edilmiştir. Tabloda görüldüğü üzere her iki kuşağın bireylerinin de takım çalışmasına önem verdikleri ancak her iki kuşağın bireylerinin de toplantılarda not tutan kişi olmayı çok fazla tercih etmedikleri söylenebilmektedir.

Tablo 15. Y ve $Z$ kuşağının İş hayatında Motivasyon Açısından Beklentileri

\begin{tabular}{|c|c|c|c|c|c|c|c|}
\hline Y Kuşağının Motivasyon Açısından Beklentileri & $\begin{array}{r}1 \\
\% \\
\mathrm{~N} \\
\end{array}$ & $\begin{array}{r}\mathbf{2} \\
\% \\
\mathrm{~N} \\
\end{array}$ & $\begin{array}{r}3 \\
\% \\
\mathrm{~N} \\
\end{array}$ & $\begin{array}{r}\mathbf{4} \\
\% \\
\mathrm{~N} \\
\end{array}$ & $\begin{array}{r}\mathbf{5} \\
\% \\
\mathrm{~N} \\
\end{array}$ & $\overline{\mathbf{x}}$ & $\mathbf{S}$ \\
\hline $\begin{array}{l}\text { 1- Birlikte çalıştığım insanların arkadaş canlılığı beni } \\
\text { motive eder. }\end{array}$ & 4,0 & 5,7 & 13,1 & 32,0 & 45,1 & 4,08 & 1,082 \\
\hline $\begin{array}{l}\text { 2- Yetenek ve becerilerimi geliştirme firsatı beni motive } \\
\text { eder. }\end{array}$ & 4,0 & 3,4 & 12,0 & 36,0 & 44,6 & 4,13 & 1,024 \\
\hline $\begin{array}{l}\text { 3- İşimde sahip olduğum özgürlük miktarı beni motive } \\
\text { eder. }\end{array}$ & 2,9 & 6,9 & 10,9 & 30,3 & 49,1 & 4,16 & 1,054 \\
\hline $\begin{array}{l}\text { 4- Değerli bir şeyleri başarma imkânının olması beni } \\
\text { motive eder. }\end{array}$ & 4,0 & 3,4 & 12,0 & 33,1 & 47,4 & 4,16 & 1,034 \\
\hline $\begin{array}{l}\text { 5- Terfi veya daha iyi bir iş bulma şansı beni motive } \\
\text { eder. }\end{array}$ & 2,9 & 5,1 & 14,3 & 28,6 & 49,1 & 4,16 & 1,038 \\
\hline 6- Yöneticimden aldığım övgü beni motive eder. & 4,0 & 5,1 & 16,0 & 27,4 & 47,4 & 4,09 & 1,094 \\
\hline Z Kuşağının Motivasyon Açısından Beklentileri & $\begin{array}{r}1 \\
\% \\
\mathrm{~N}\end{array}$ & $\begin{array}{c}2 \\
\% \\
\mathrm{~N}\end{array}$ & $\begin{array}{c}3 \\
\% \\
\mathrm{~N}\end{array}$ & $\begin{array}{r}4 \\
\% \\
\mathrm{~N}\end{array}$ & $\begin{array}{c}5 \\
\% \\
\mathrm{~N}\end{array}$ & $\overline{\mathbf{x}}$ & $\mathbf{S}$ \\
\hline $\begin{array}{l}\text { 1- Birlikte çalıştığım insanların arkadaş canlılığı beni } \\
\text { motive eder. }\end{array}$ & 6,9 & 2,9 & 13,7 & 27,4 & 49,1 & 4,09 & 1,165 \\
\hline $\begin{array}{l}\text { 2- Yetenek ve becerilerimi geliştirme firsatı beni motive } \\
\text { eder. }\end{array}$ & 2,3 & 6,3 & 9,1 & 26,9 & 55,4 & 4,26 & 1,018 \\
\hline $\begin{array}{l}\text { 3- İşimde sahip olduğum özgürlük miktarı beni motive } \\
\text { eder. }\end{array}$ & 4,0 & 3,4 & 13,7 & 32,6 & 46,3 & 1,04 & 1,041 \\
\hline $\begin{array}{l}\text { 4- Değerli bir şeyleri başarma imkânının olması beni } \\
\text { motive eder. }\end{array}$ & 2,9 & 4,0 & 9,1 & 33,1 & 50,9 & $\begin{array}{r}0,97 \\
9 \\
\end{array}$ & $\begin{array}{r}0,979 \\
4\end{array}$ \\
\hline $\begin{array}{l}\text { 5- Terfi veya daha iyi bir iş bulma şansı beni motive } \\
\text { eder. }\end{array}$ & 1,7 & 5,1 & 12,0 & 32,6 & 48,6 & $\begin{array}{r}0,96 \\
2 \\
\end{array}$ & $\begin{array}{r}0,962 \\
4 \\
\end{array}$ \\
\hline 6- Yöneticimden aldığım övgü beni motive eder. & 2,3 & 6,3 & 15,4 & 28,0 & 48,0 & 1,03 & 1,039 \\
\hline
\end{tabular}

Tablo 8'deki analiz sonucuna göre Y kuşağ1 bireylerinin motivasyon ifadelerine verdikleri yanıtların ortalamasına göre beklentileri 4,13 iken $Z$ kuşağı bireylerinin 4,18'dir. Tablo 15'e göre, yapılan işte sahip olunan özgürlük miktarı $(4,16)$, terfi veya daha iyi bir iş bulma şansı 
$(4,16)$ ve değerli bir şeyleri başarma imkânının olması $(4,16)$ Y kuşağı bireylerini aynı oranda motive ederken yetenek ve becerilerini geliştirme firsatı $(4,13)$, yöneticiden alınan övgü $(4,09)$ ve önem derecesine göre en son sırada yer alan birlikte çalışılan insanların arkadaş canlılığ $(4,08)$ Y kuşağ 1 bireyleri için motive edici faktörler arasındadır. Buna karşılık $Z$ kuşağ bireylerini en fazla motive eden faktör ise yetenek ve becerilerini geliştirme fırsatıdır $(4,26)$. Ardından sırasıyla birlikte çalıştığı insanların arkadaş canlılığı, işte sahip olunan özgürlük miktarı, yöneticiden alınan övgü, değerli bir şeyleri başarma imkânı ve terfi veya daha iyi bir iş bulma şansını gelmektedir.

Tablo 16. Y ve $Z$ kuşağının İş hayatında Gelişme Açısından Beklentileri

\begin{tabular}{|c|c|c|c|c|c|c|c|}
\hline Y Kuşağının Gelişme Açısından Beklentileri & $\begin{array}{r}1 \\
\% \\
\mathrm{~N}\end{array}$ & $\begin{array}{r}\mathbf{2} \\
\% \\
\mathrm{~N}\end{array}$ & $\begin{array}{c}3 \\
\% \\
\mathrm{~N}\end{array}$ & $\begin{array}{c}\mathbf{4} \\
\% \\
\mathrm{~N}\end{array}$ & $\begin{array}{r}\mathbf{5} \\
\% \\
\mathrm{~N}\end{array}$ & $\mathbf{x}$ & $\mathbf{S}$ \\
\hline $\begin{array}{l}\text { 1- Şirketim yeni yetenekler geliştirebilmem için } \\
\text { bana firsat sunmall. }\end{array}$ & 5,1 & 3,4 & 14,3 & 35,4 & 41,7 & 4,05 & 1,078 \\
\hline $\begin{array}{l}\text { 2- Şirketim terfi şansımı artırabilmem için fırsatlar } \\
\text { sunmalı. }\end{array}$ & 4,0 & 2,3 & 10,3 & 38,9 & 44,6 & 4,17 & 0,9870 \\
\hline $\begin{array}{l}\text { 3- Sirketim bana daha fazla teknik bilgi } \\
\text { edinebilmek için firsatlar sunmall. }\end{array}$ & 5,1 & 4,0 & 9,1 & 37,7 & 44,0 & 4,11 & 1,071 \\
\hline $\begin{array}{l}\text { 4- Şirketim bana ürünler ve hizmetler hakkında } \\
\text { daha fazla bilgi edinme fırsatı sunmalı. }\end{array}$ & 3,4 & 3,4 & 12,6 & 38,3 & 42,3 & 4,12 & 0,9920 \\
\hline $\begin{array}{l}\text { 5- Sirketim yabancı dil yeteneklerimi } \\
\text { geliştirebilmem için firsatlar sunmalı. }\end{array}$ & 4,6 & 3,4 & 16,6 & 26,9 & 48,6 & 4,11 & 1,092 \\
\hline $\begin{array}{l}\text { 6- Sirketim eğitimime devam etmemi sağlayacak } \\
\text { olanakları sağlamalı. }\end{array}$ & 5,7 & 3,4 & 9,1 & 25,7 & 56,0 & 4,22 & 1,121 \\
\hline \multirow[b]{2}{*}{ Z Kuşağının Gelişme Açısından Beklentileri } & 1 & 2 & 3 & 4 & 5 & & \\
\hline & $\begin{array}{l}\% \\
\mathrm{~N}\end{array}$ & $\begin{array}{l}\% \\
\mathrm{~N}\end{array}$ & $\begin{array}{l}\% \\
\mathrm{~N}\end{array}$ & $\begin{array}{l}\% \\
\mathrm{~N}\end{array}$ & $\begin{array}{c}\% \\
\mathrm{~N}\end{array}$ & $\bar{x}$ & $\mathbf{S}$ \\
\hline $\begin{array}{l}\text { 1- Şirketim yeni yetenekler geliştirebilmem için } \\
\text { bana firsat sunmall. }\end{array}$ & 4,6 & 5,1 & 13,1 & 37,1 & 40,0 & 4,02 & 1,074 \\
\hline $\begin{array}{l}\text { 2- Şirketim terfi şansımı artırabilmem için fırsatlar } \\
\text { sunmalı. }\end{array}$ & 2,3 & 3,4 & 16,0 & 33,1 & 45,1 & 4,15 & 0,9673 \\
\hline $\begin{array}{l}\text { 3- Sirketim bana daha fazla teknik bilgi } \\
\text { edinebilmek için firsatlar sunmall. }\end{array}$ & 2,3 & 5,1 & 13,1 & 33,7 & 45,7 & 4,15 & 0,9908 \\
\hline $\begin{array}{l}\text { 4- Sirketim bana ürünler ve hizmetler hakkında } \\
\text { daha fazla bilgi edinme firsatı sunmalı. }\end{array}$ & 2,3 & 5,7 & 12,0 & 37,1 & 42,9 & 4,12 & 0,9862 \\
\hline $\begin{array}{l}\text { 5- Şirketim yabancı dil yeteneklerimi } \\
\text { geliştirebilmem için firsatlar sunmalı. }\end{array}$ & 3,4 & 7,4 & 10,9 & 29,7 & 48,6 & 4,12 & 1,091 \\
\hline $\begin{array}{l}\text { 6- Sirketim eğitimime devam etmemi sağlayacak } \\
\text { olanakları sağlamalı. }\end{array}$ & 2,9 & 2,9 & 10,9 & 23,4 & 60,0 & 4,34 & 0,9818 \\
\hline
\end{tabular}

Tablo 8'deki analiz sonucuna göre Y kuşağı bireylerinin gelişme ifadelerine verdikleri yanıtların ortalamasına göre beklentileri 4,13 iken Z kuşağ1 bireylerinin 4,15'dir. Tablo 16'ya göre hem Y hem $Z$ kuşağı bireyleri, kendilerinin gelişimi için şirketin eğitimine devam etmelerini sağlayacak olanakları sağlamasını birinci sırada önemli görmektedir. Bunu her iki kuşak için de şirketin terfi şansını artırabilmeleri için fırsatlar sunması takip etmektedir. Ardından Y kuşağı için şirketin ürün ve hizmetler hakkında daha fazla bilgi sunması ve daha fazla teknik bilgi edinebilme firsatı önem taşırken $Z$ kuşağı için ise şirketin daha fazla teknik bilgi edinebilme firsatı sunması ve ürün ve hizmetler hakkında daha fazla bilgi sunması gelmektedir. Her iki kuşağın bireyleri için şirketin yabancı dil yeteneğini ve yeni yetenekler geliştirebilme için fırsatlar sunması aynı derecede önem taşımaktadır. Bu sonuçlardan anlaşılacağı üzere her iki kuşakta gelişim olanaklarına oldukça fazla önem vermektedir.

\section{SONUC}

Bugün ilk doğanı 40 yaşında olan ve hala iş hayatında olan Y kuşağı ile bugün ilk doğanı henüz 20 yaşlarında olan ve yeni yeni iş hayatına girmekte olan $Z$ kuşağı bireylerinin iş hayatından beklentilerinin belirlenmeye çalışıldığı bu çalışmada her iki kuşağın bireylerinin iş hayatından beklentilerinin anlamlı ölçüde farklılaşmadığı sonucuna ulaşılmakla birlikte örgüt kültürü, 
lider, motivasyon, takım çalışması ve gelişim boyutlarında yer alan ifadeler açısından farklılaştığı iletişim ve karar verme boyutlarında yer alan ifadeler açısından ise aynı olduğu sonucu elde edilmiştir.

Bu araştırmada hem $Y$ hem de $Z$ kuşağının iş hayatından beklentilerinin özellikle örgüt kültürü, motivasyon ve gelişim konularında daha önemli olduğu sonucu elde edilmiştir. Araştırmanın sonucuna göre örgüt kültürü açısından hem $Y$ hem de $Z$ kuşağı için işletmeler, müşterilerini dinlemeli ve onların gereksinimlerine cevap vermelidir. Bununla birlikte her iki kuşak için de takım halinde uyumlu çalışmak ve çalışanların birbirine değer verdiği işletmelerde çalışmak önem kazanmaktadır.

Ayrıca araştırmanın sonucuna göre $Y$ ve $Z$ kuşağı bireylerinin eğitime ve kişisel gelişime önem verdikleri söylenebilmektedir. Dolayısıyla her iki kuşak da kendilerini geliştirmelerine fırsat veren kurumlarda çalışmak isteyecektir.

Y kuşağ bireyleri için işte sahip olunan özgürlük miktarı, terfi ya da daha iyi bir iş bulma şansı ve değerli bir şeyleri başarma imkânı onları motive eden unsurların başında gelmekle birlikte iş hayatına yeni girmiş ya da girecek olan $Z$ kuşağı bireylerini en fazla motive edecek olan unsur yetenek ve becerilerini geliştirme fırsatı ve birlikte çalışılan insanların canlllı̆̆ıdır.

Bunun yanı sıra $Z$ kuşağı bireyleri için eğitim, daha fazla teknik bilgi elde edebilmelerini sağlayan, terfi için firsatlar sunan, yabancı dil yeteneklerini geliştirmelerine firsat sunan, ürünler ve hizmetler hakkında daha fazla bilgi sağlayan işletmelerle çalışmak onları daha da mutlu edecek, daha da motive olmasını sağlayacak ve bu şekilde bu firsatları sunan işletmelerin de amaçlarına daha kolay bir şekilde ulaşma olasıllığ artacaktır.

Her iki kuşağın da takım çalışmasına önem verdiği sonucuna ulaşılmış olmakla birlikte her iki kuşağın bireylerinin de gerçek bilgilere göre karar almaya önem verdikleri ancak bunun yanı sıra içgüdü ve tepkilerini de göz ardı etmedikleri görülmektedir.

İletişim noktasında her iki kuşağın bireyleri de insanlarla nazik bir tarzda konuşmanın ve yardımsever olmanın önemine değinmekle birlikte iş arkadaşlarının problemlerini dinlemenin de önemli olduğuna değinmişlerdir. Başkaları ile sohbet etmekten keyif alan $Y$ ve $Z$ kuşakları düşüncelerini de özgür bir şekilde paylaşabilmeyi arzu etmektedir.

Y kuşağı bireylerinin liderden beklentileri içerisinde birinci sırada standartlara uymayan durumlarda yöneticilerinden uyarılmayı bekledikleri sonucu elde edilmiştir. $Z$ kuşağı ise yöneticiden gelecekte karşılaşabileceği firsatlara göre bir vizyon oluşturmasını beklemektedir. Ayrıca her iki kuşağın bireyleri de iş hayatlarında yapılması gerekenleri yaptıklarında ne elde edeceklerini açıkça yöneticilerinden duymayı tercih etmektedir.

$\mathrm{Y}$ ve $\mathrm{Z}$ kuşaklarının iş hayatından beklentilerinin karşılaştırıldığı bu çalışmada elde edilen sonucu özetlemek gerekirse $Z$ kuşağı için söylenebilecekler şunlardır; eğitim ve gelişimlerine önem veren, karar alırken realist davranışlar sergileyen ancak yine de sezgilerini de tamamen göz ardı etmeyen bu kuşak bireyleri yöneticilerinin gelecekte karşılaşılması muhtemel durumlara göre bir vizyon oluşturmasını, standartlara uymayan durumlarda yönetici tarafından uyarılmayı, yapılması gerekenleri yaptıklarında ne elde edeceklerini yöneticilerinden açıkça duymayı, düzeltilmesi gereken hataları için yöneticinin performans izlemesini ve çabaları karşıllığında ödüllendirilebilmesi için ne yapmaları gerektiğini söylemesini istemektedir.

Ayrıca müşterilerin ihtiyaçlarına hızlı yanıt veren, çalışanlarının daha verimli olabilmesi için daima yollar arandığı, takım halinde uyumlu çalışıldığı, çalışanların kişisel problemlerinin üstesinden gelebilmesi için çözüm yollarının arandığı ve çalışanların birbirine değer verdiği bir 
örgüt kültürüne sahip bir işletmede çalışmayı arzu eden $Z$ kuşağ insanlarla konuşurken nazik ve yardımsever olmayı tercih etmekle birlikte iş arkadaşlarının problemlerini dinleyen ve kendi düşüncelerini de başkalarıyla özgürce paylaşmayı tercih eden bir yaklaşım sergilemektedir. Bunlara karşılık Z kuşağının aklına ilk geleni söyleme ve iş arkadaşlarına uzun ve kesin talimatlar verme konularını çok arzulamadıkları analiz sonucunda elde edilmektedir.

Dolayısıyla geleceğin çalışanları olacak olan Z kuşağı ile çalışacak olan yöneticilerin Z kuşağını önceki kuşaklardan ayıran özelliklerin farkında olup ona göre bir yaklaşım sergilemesi gerekmektedir. Z kuşağını daha iyi tanıyan işletme üst düzey yöneticilerinin çalışanları ile iyi ilişkiler geliştirmesi olasılığı yüksek olacak bu durum da çalışanların işletmenin amaçları için daha özverili çalışmalarına yol açacak dolayısıyla işletmenin hayatta kalma, amaçlarına ulaşma ve rekabet üstünlüğünü ele geçirme şansı daha da artacaktır.

Kuşaklarla ilgili birçok araştırma yapılmış olmasına rağmen özellikle $Z$ kuşağı ile ilgili Türkiye'de yapılan çalışmalar kısıtlıdır. Bu nedenle özellikle $Z$ kuşağı ile ilgili daha fazla çalışma yapılması önerilmektedir. Ayrıca bu çalışma $Y$ ve $Z$ kuşakları dikkate alınarak yapılmıştır. Bundan sonraki çalışmalarda $Z$ kuşağından sonra gelen Alpha kuşağı da dikkate alınarak çalışmalar yapılması önerilmektedir. Çalışmanın yalnızca Gümüşhane Üniversitesi öğrencilerine yapılmış olması araştırmanın diğer bir kısıtını oluşturmaktadır. Dolayısıyla gelecekte daha kapsamlı çalışmalar yapılması iş hayatından beklentinin Y ve Z kuşağına göre farklılık gösterip göstermediğini ortaya koyması açısından faydalı olacaktır.

Etik Kurul Onay1: Gümüşhane Üniversitesi Bilimsel Araştırma ve Yayın Etiği Kurulu'nun 2020/4 sayı ve 07.04.2020 tarihli toplantısında görüşülmüş ve kabul edilmiştir.

\section{KAYNAKÇA}

Alwin, D. F., ve McCammon, R. J. (2007). Rethinking generations. Research in Human Development, 4(3-4), 219-237. doi: 10.1080/15427600701663072.

Biggs, S. (2007). Thinking about generations: Conceptual positions and policy implications. Journal of social issues, 63(4), 695-711. Erişim adresi: https://spssi.onlinelibrary.wiley.com/doi/pdf/10.1111/j.15404560.2007.00531.x?casa_t oken=AyoiRVRt1osAAAAA:q9cTDp5ie3cMXHL5CEPd5oGnSpSW0xXF0rGUUDBsnfnObtbR szUoykeI3GGacrRsookHmSVwwJt7AWmD.

Broadbridge, A. M., Maxwell, G. A., ve Ogden, S. M. (2007). 13_2_30: Experiences, Perceptions and Expectations of Retail Employment for Generation Y. Career Development International, 1-39. Erişim adresi: https://dspace.stir.ac.uk/bitstream/1893/681/1/ Rerevised\%20final\%20Generation\%20Y\%20journal\%20Article\%20(CDI\%20-\%2011.05.pdf

Buckley, M. R., Beu, D. S., Novicevic, M. M., ve Sigerstad, T. D. (2001). Managing generation next: Individual and organizational perspectives. Review of Business, 22, 81-85. Erişim adresi: $\quad$ http://eds.b.ebscohost.com/eds/pdfviewer/pdfviewer?vid=0\&sid=5ad9e9481c18-4d12-9eca-a42dfe4991d4\%40pdc-v-sessmgr02

Büyüköztürk, Ş. (2007). Sosyal bilimler için veri analizi el kitabı. Ankara: Pegem A Yayıncılık.

Carolyn, A. M. (2005). From high maintenance to high productivity. What managers need to know about Generation Y. Industrial and Commercial Training, 37(1), 39-44. Erissim adresi:https://pdfs.semanticscholar.org/3612/639dc3546f86f7c411065d720cac29da306 a.pdf 
Glass, A. (2007). Understanding generational differences for competitive success. Industrial and commercial training, 98-103. doi:10.1108/00197850710732424

Golovinski, M. S. (2011). Event 3.0: How Generation $Y \& Z$ are Re-shaping the Events Industry.

Green, B. (2006). Marketing to Leading-edge Baby Boomers: Perceptions, Principles, Practices, Predictions. New York, ABD: Paramount Market Publishing.

Jurkiewicz, C. L. (2000). Generation X and the public employee. Public Personnel Management, 29(1), 55-74. Erişim adresi: http://eds.b.ebscohost.com/eds/pdfviewer/ pdfviewer?vid=0\&sid=d6c00279-4426-44e3-ae07-c4270b2a4b78\%40pdc-v-sessmgr0 1

Jusoh, M., Simun, M., ve Chong, S. C. (2011). Expectation gaps, job satisfaction, and organizational commitment of fresh graduates: Roles of graduates, higher learning institutions and employers. Education+ Training, 53(6), 515-530. doi: $10.1108 / 00400911111159476$

Kalaycı, S. (2008). SPSS uygulamalı çok değişkenli istatistik teknikleri. Ankara: Asil Yayın Dağıtım Ltd. Şti.

Kerstein, D. (2014). Today's generations face new communication gaps. USA Today. Erişim adresi: http://www.kcnawic.org/uploads/4/4/7/2/4472081/04-15-2014.pdf

Levickaite, R. (2010). Generations X, Y, Z: How social networks form the concept of the world without borders (the case of Lithuania). LIMES: Cultural Regionalistics, 3(2), 170-183. doi: $10.3846 /$ limes. 2010.17

Lower, J. (2008). Brace Yourself Here Comes Generation Y. Critical Care Nurse.28(5), 80-84. Erişim adresi: http://web.a.ebscohost.com/ehost/pdfviewer/pdfviewer?vid=0\&sid =5ce6e339-7b68-4eb7-87a8-7bee257066e4\%40sdc-v-sessmgr02

Mishra, R. K., Sarkar, S., ve Singh, P. (Eds.). (2012). Today's HR for a sustainable tomorrow (Vol. 1). Allied Publishers.

O'Bannon, G. (2001). Managing our future: The generation X factor. Public Personnel Management, 30(1), 95-110. Erişim adresi: http://web.a.ebscohost.com/ehost/ pdfviewer / pdfviewer?vid=0\&sid=104fdf47-30fb-4b1f-8322-56026e355859\%40sdc-vsessmgr03

Rothman, D. (2014) A tsunami of learners called generation $Z$. Erişim adresi: https://mdle.net/Journal/A_Tsunami_of_Learners_Called_Generation_Z.pdf

Schawbel, D. (2014). The High School Careers Study. Erişim adresi: https://ct2.cpiworld.com/ PortalFiles/9d9037e1-4726-430f-baa1-b14948fbfOf3.pdf

Sladek, B. S., ve Grabinger, A. (2016). The first generation of the 21st Century has arrived!, 16. Erişim adresi: https://www.xyzuniversity.com/wp-content/uploads/2018/08/GenZ_ Final-dl1.pdf

Srinivasan, V. (2012). Multi generations in the workforce: Building collaboration. IIMB Management Review, 24(1), 48-66. doi:10.1016/j.iimb.2012.01.004

Sullivan, S. E., Forret, M. L., Carraher, S. M., ve Mainiero, L. A. (2009). Using the kaleidoscope career model to examine generational differences in work attitudes. Career Development International. Erişim adresi: https://digitalcommons.fairfield.edu/cgi/viewcontent.cgi ?article $=1057 \&$ context $=$ business-facultypubs 
Şencan, H. (2002). Bilimsel yazım, İstanbul Üniversitesi, İşletme Fak. Yayınları.

Tapscott, D. (2009). Grown up digital. Boston: McGraw-Hill Education. Erişim adresi: https://studynotesunisa.co.za/wp-content/uploads/2018/12/grown-up-digital-tapscotte.pdf.

Taşliyan, M., Eyitmiş, A., ve Günduğdu, E. (2015). Y kuşağ1 iş yaşamından ne bekliyor. Kahramanmaraş Sütçü İmam Üniversitesi İktisadi ve İdari Bilimler Fakültesi Dergisi, 4(2), 19-32.

Tolbize, A. (2008). Generational differences in the workplace. Research and training center on community living, 5(2), 1-21. Erişim adresi: https://rtc3.umn.edu/docs/2_18_ Gen_diff_workplace.pdf

Tulgan, B., ve Martin, C. A. (2001). Managing Generation Y: Global citizens born in the late seventies and early eighties. Human Resource Development.

Twenge, J. M., Campbell, S. M., Hoffman, B. J., ve Lance, C. E. (2010). Generational differences in work values: Leisure and extrinsic values increasing, social and intrinsic values decreasing. Journal of management, 36(5), 1117-1142. doi: 10.1177/0149206309352246.

Bayhan, V. (2017). Gençlik ve Kuşaklar: Kuşaklara Göre Gençliğin Değer ve Davranışlan. Zencirkıran, M. (Ed.), Davranış Bilimleri içinde (322), Bursa: Dora Yayınevi. 


\section{SUMMARY}

\section{Introduction}

The characteristics of people living in different periods vary according to the conditions of their time. As a result of this situation, differences between generations and generations has been emerged. The generational differences, which are a reflection of these changes and developments, also affect the business life. Therefore, businesses that want to reach their goals should be aware that their expectations of employee change from business life and in order to keep their employees, they need to do some activities such as knowing their characteristics, changing and improving their working conditions. Although the generation $\mathrm{Y}$ is still active in today's business life, the generation $z$ that is born and growing in technology will take more place in business life in the coming years. It is thought that the different thinking structure of the $\mathrm{Z}$ generation, which will take place more in business life, will make important contributions to business life.

\section{Purpose}

The main purpose of this research is to reveal the expectations of the generations named Y and $Z$ from business life, to compare the expectations of these generations and to transmit these to light the way for their executives.

\section{Method}

The questionnaire form used in the research was applied to the students of Gümüşhane University and the data obtained from the questionnaire was used. Test $\mathrm{T}$ analysis was used for independent groups in the research.

\section{Findings}

According to the result of the research, it was concluded that the expectations of the $\mathrm{Y}$ and $\mathrm{Z}$ generation individuals from business life did not differ significantly. In other words, it has been concluded that it differs in terms of organizational culture, leader, motivation, teamwork and development, and that it is the same in terms of communication and decision making. In this study, it was concluded that the expectations of both $\mathrm{Y}$ and $\mathrm{Z}$ generation from business life are more important especially in organizational culture, motivation and development.

To summarize the results obtained in this study where the expectations of the generations of $Y$ and $Z$ from business life are compared, what can be said about the generation $Z$ are;

These generation individuals who attach importance to their education and development, display realist behavior while making decisions, but still do not completely ignore their intuition want their managers to create a vision based on possible situations in the future, to be warned by the manager in situations that do not meet the standards, to hear clearly from their managers what they will get when they do what they have to do, the manager to monitor the performance for the errors that need to be corrected and to tell what to do so that they can be rewarded for their efforts by the managers.

Additionally, the generation $z$ that wishes to work in a business that has an organizational culture that responds quickly to the needs of customers, that always looks for ways to make its employees more efficient, that workes harmoniously as a team, in which solutions are sought to overcome the personal problems of the employees, where employees value each other prefers to 
be kind and helpful when talking to people. In addition, the generation $z$ takes an approach that listens to the problems of colleagues and prefers to share their thoughts freely with others.

On the other hand, it has obtained as a result of the analysis that generation $Z$ does not desire so much the subjects of saying the first thing that comes to mind and giving long and precise instructions to their colleagues.

\section{Conclusion}

As a result, the managers who will work with the generation $Z$ who will be the employees of the future should be aware of the features that distinguish the generation $Z$ from the previous generations. Because the business executives who know the generation $Z$ better will have a high probability of developing good relations with their employees. This situation will lead employees more self-sacrificing for the goals of the business's objectives, in this way the chances of the business to survive, achieve its goals and gain competitive advantage will increase. 